\title{
Cộng đồng Baha'i Việt Nam trong thực hiện chức năng xã hội trên địa bàn Thủ đô Hà Nội
}

\section{Vietnamese Baha'i community in performing social functions in Hanoi capital}

\author{
Vũ Văn Chung ${ }^{1 *}$ \\ ${ }^{1}$ Trường Đại học Khoa học Xã hội và Nhân văn, ĐHQG Hà Nội, Việt Nam \\ *Tác giả liên hệ, Email: vuchung83@gmail.com
}

THÔNG TIN

DOI: $10.46223 / \mathrm{HCMCOUJS}$.

soci.vi.16.2.1987.2021

Ngày nhận: 07/07/2021

Ngày nhận lại: 31/07/2021

Duyệt đăng: 07/08/2021

Tù khóa:

Baha'i; chức năng xã hội; Hà Nội; hoạt động tôn giáo; tôn giáo

Keywords:

Baha'i; social functions; Hanoi; religious activities; religion; social activities

\section{TÓM TẮT}

Baha'i là một tôn giáo du nhập vào Việt Nam từ những năm 1920, nửa đầu thế kỷ XX. Tuy nhiên, để có thể tồn tại và phát triển như hiện nay, Cộng đồng tôn giáo này đã trải qua quá trình với nhiều thăng trầm và biến đổi. Trong suốt những năm qua, Cộng đồng Baha'i Việt Nam đã có sự phát triển mạnh mẽ ở nhiều địa phương trong cả nước, đặc biệt ở nhiều tỉnh miền Bắc như Phú Thọ, Vĩnh Phúc, Nam Định, Bắc Giang, Sơn La, Hoà Bình, Hải Phòng và Hà Nội ... Trong phạm vi của thủ đô Hà Nội, cộng đồng Baha'i đang có những hoạt động thể hiện các chức năng xã hội của mình trên một số lĩnh vực: giáo dục đạo đức, lối sống; tham gia từ thiện an sinh xã hội; tham gia bảo vệ môi trường; ... Cộng đồng Baha'i Việt Nam với những tổ, đội, nhóm, hội đoàn tín đồ nhỏ tạo thành một mạng lưới quan hệ xã hội cấu thành từ các cá nhân cùng chung tín ngưỡng, niềm tin vào Thượng Đế. Bài viết này tiếp cận vấn đề nghiên cứu từ các lý thuyết được phát triển gần đây về chức năng xã hội của tôn giáo để phân tích và làm rõ vai trò của cộng đồng Baha'i trong thực hiện chức năng xã hội trên địa bàn thủ đô.

\section{ABSTRACT}

Baha' $i$ is a religion introduced to Vietnam in the 1920s, the first half of the twentieth century. However, to survive and develop as it is today, this religious community has gone through a process with many ups and downs and changes. During the past years, the Vietnamese Baha'i Community has had a strong development in many localities throughout the country, especially in many northern provinces such as Phu Tho, Vinh Phuc, Nam Dinh, Bac Giang, and Son La, Hoa Binh, Hai Phong, and Hanoi, etc. In the Hanoi capital, the Baha'i community has activities that demonstrate their social functions on many fields: moral education, lifestyle; participate in social charity; participate in environmental protection, etc. Vietnamese Baha'i community, this religious community with its small team, groups, and associations of believers forms a network of social relations made 
up of individuals who share the same beliefs and faith in the God. This article approaches the research problem from recently developed theories on the social function of religion to analyze and clarify the role of the Baha'i community in performing social tasks in the capital.

\section{Giới thiệu}

Trong đời sống tôn giáo hiện nay, xu hướng thế tục hoá là một nhu cầu của thời đại. Thế tục hoá là quá trình dấn thân của các tôn giáo nhằm thể hiện chức năng xã hội của mình ở nhiều lĩnh vực khác nhau, bao gồm cả kinh tế, chính trị, văn hoá, ... Các tôn giáo đóng góp ngày càng nhiều hơn cho xã hội từ phương diện đời sống vật chất lẫn đời sống tinh thần. Không chỉ góp phần xây dựng, củng cố đạo đức hướng thiện, giáo lối sống nhân văn mà còn cả trong lĩnh vực bảo vệ môi trường sống, vì một xã hội bền vững, bảo vệ bình đẳng giới và tích cực hơn trong các hoạt động từ thiện, an sinh vì sự an toàn xã hội. Tôn giáo giúp cho nhân loại khai mở chân lý tâm linh thông qua đường hướng và phương châm hành động cụ thể gắn với mục tiêu "công bằng, dân chủ, văn minh.” Trên tinh thần căn bản đó, tôn giáo Baha'i mặc dù vào Việt Nam từ năm 1920, nửa đầu thế kỉ XX, trải qua không ít những khó khăn, thử thách và biến đổi không ngừng để tồn tại, phát triển, khẳng định mình. Sau 90 năm, tháng 03 năm 2007, Chính phủ Việt Nam đã cấp chứng nhận đăng ký hoạt động cho Baha'i (Hong Ly, 2008, pp. 5, 28) dưới sự điều hành của Hội đồng tinh thần Baha'i Việt Nam. Ngày 14 tháng 07 năm 2008, Ban Tôn giáo Chính Phủ ký quyết định công nhận tổ chức cho cộng đồng Baha'i Việt Nam (Hong Ly, 2008, pp. 5, 28). Gần 15 năm, từ khi được công nhận tổ chức, cộng đồng Baha'i Việt Nam đã bước đầu có sự phát triển và dấn thân, nhập thế, hoà mình vào xã hội hơn trên con đường hướng đạo.

Nghiên cứu về thực hiện chức năng xã hội của tôn giáo Baha'i ở Việt Nam nói chung và thủ đô Hà Nội nói riêng là mảng đề tài còn khá mới, hiện chưa có nhiều công trình quan tâm, tìm hiểu. Bước đầu giới nghiên cứu Tôn giáo nước ta đã có một số công trình công bố về cộng đồng Baha'i Việt Nam. Tuy nhiên, nghiên cứu về cộng đồng tôn giáo Baha'i Hà Nội và nhất là chức năng xã hội của họ trên địa bàn thủ đô Hà Nội hiện nay thì dường như còn vắng bóng. Đây chính là khoảng trống để tác giả lựa chọn chủ đề này. Qua bài viết, tác giả hi vọng sẽ cố gắng làm rõ chức năng xã hội của tôn giáo Baha'i trong hoạt động cộng đồng tại thủ đô thông qua lăng kính tiếp cận về lý thuyết chức năng xã hội của tôn giáo.

\section{Co' sở lý thuyết}

Nghiên cứu về chức năng xã hội của tôn giáo, hiện có nhiều công trình trong nước và quốc tế quan tâm. Những công bố này, các tác giả cũng đưa ra được những đánh giá, nhận định khái quát về vấn đề nghiên cứu. Chức năng xã hội của tôn giáo được các học giả tiếp cận và phân tích từ một số khía cạnh cơ bản: trên bình diện của quan điểm duy vật Mác xít; từ phương diện xã hội học với quan điểm của Durkheim (2008), Weber (1993); từ phương diện nhân học văn hoá với quan điểm của Malinowski (2010), ...

Chức năng xã hội của tôn giáo tiếp cận từ quan điểm Mác xít bao gồm các chức năng căn bản như đền bù hư ảo, điều chỉnh liên kết, giao tiếp, thế giới quan, ... Mỗi chức năng được bộc lộ ra trong xã hội là khác nhau trên nhiều bình diện của đời sống từ tinh thần đến vật chất. Nhu cầu về vật chất và tinh thần là hai nhu cầu không thể thiếu của con người, ngoài ra nhu cầu được thoả mãn về đời sống tâm linh cũng luôn thường trực và là nhu cầu chính yếu. Ở khía cạnh này, tôn giáo sẽ góp phần xoa dịu, làm nhẹ nỗi đau trần thế, hướng con người tới chốn linh thiêng. Niềm tin vào đấng tối cao, mong được sự che chở, cứu vớt thường tạo cho con người cảm nhận được bù đắp, trấn an, hạnh phúc mặc dù chỉ là "hạnh phúc hư ảo," hạnh phúc trong lĩnh vực tinh thần. "Sự nghèo nàn của tôn giáo vừa là biểu hiện của sự nghèo nàn hiện thực, vừa là sự phản kháng 
chống sự nghèo nàn hiện thực ấy. Tôn giáo là tiếng thở dài của chúng sinh bị áp bức, là trái tim của thế giới không có trái tim, cũng như nó là tinh thần của những trật tự không có tinh thần. Tôn giáo là thuốc phiện của nhân dân" (Marx \& Engels, 1995, pp. 437-570).

Theo lý thuyết chức năng xã hội của tôn giáo từ góc độ tiếp cận xã hội học tôn giáo, E. Durkheim (1858 - 1917) (Durkheim, 2008), cho rằng đó chính là sự tạo dựng và duy trì tính bền vững và thống nhất của luân lý, đạo đức xã hội: "Sự phấn khích do xã hội sinh ra vào buổi khởi đầu của mọi hoạt động tôn giáo: ý niệm tôn giáo nảy sinh trong môi trường xã hội khích động. Vấn đề là từ khi con người sống cùng nhau thành một nhóm trong một mái ấm thì một sự sôi sùng sục về quan hệ và đạo đức đã được tạo $\mathrm{ra}$... Bằng đức tin của chính mình, tín đồ thể hiện lòng tín ngưỡng và sự tin cậy vào một đức Chúa mà đó không phải ai khác ngoài xã hội; xã hội đem lại một sức mạnh tinh thần cho các tín đồ" (Olivier Bobineau Sebastien Tank Storper, 2012, p. 19). Hay theo Weber "Đạo đức tôn giáo, trong ý tín đồ của nó muốn hợp lý hoá thế giới trên bình diện đạo đức thực hành” (Olivier Bobineau Sebastien Tank Storper, 2012, p. 47).

Đứng trên phương diện tiếp cận nhân học văn hoá, lý thuyết chức năng xã hội của tôn giáo Malinowski khẳng định: "tôn giáo là phần thiêng liêng, nâng đỡ cho con người vào những thời khắc trọng đại, an ủi và đem lại hy vọng những khi cá nhân cô đơn nhất, hoảng sợ nhất (khi đứng trước cái chết, chẳng hạn); tôn giáo xoay quanh những hoạt động sống còn của con người hay cả nhóm cộng đồng" (Malinowski, 2006, pp. 180-189).

Để xác lập được cơ sở phân tích việc thực hiện chức năng xã hội của tôn giáo và Cộng đồng Baha'i nước ta, tác giả còn dựa vào lý thuyết thực thể tôn giáo nhằm đánh ảnh hưởng của tôn giáo đến xã hội ở các khía cạnh: tần suất tác động, phương diện ảnh hưởng và cơ chế tác động đối với các tín đồ và cộng đồng xã hội. Trường phái lý thuyết này là TyLor (2001), Weber (1993), ... Khi phân tích ảnh hưởng của thực thể tôn giáo, Weber (1993) chú trọng đến khái niệm "hành động xã hội”, là những việc làm có tính định hướng tác động đến xã hội. "Tôn giáo không phải ưu tiên là những hệ thống tín ngưỡng, mà chúng là những hệ thống quy chế của cuộc sống đã biết tập hợp xung quanh chúng những khối quần chúng đặc biệt quan trọng là các tín đồ ... trong chừng mực của một thực thể tôn giáo, ... những xui khiến thực tế dẫn đến hành động, những xui khiến được bắt rễ ở các khớp nối tâm lý và tính thực dụng của các tôn giáo, ... Tôn giáo là một loại cư xử đặc biệt trong cộng đồng, vấn đề là phải nghiên cứu những hoàn cảnh phát triển và tác động của nó lên đời sống cá nhân và cộng đồng xã hội" (Olivier Bobineau Sebastien Tank Storper, 2012, pp. 30-31). Việc làm rõ được nội dung này nhằm tạo ra tiền đề cơ sở lý thuyết quan trọng trong nghiên cứu tôn giáo và là căn cứ khách quan cho tác giả phân tích chức năng xã hội của tôn giáo Baha'i trong thực tiễn tại thủ đô Hà Nội.

Bài viết này, tác giả giới hạn phạm vi nghiên cứu, là về cộng đồng Baha'i Việt Nam trong thực hiện chức năng xã hội trên địa bàn Hà Nội. Mỗi tín đồ Baha'i thủ đô sinh hoạt tôn giáo trong Cộng đồng tinh thần Baha'i đều có cùng một mục đích hoạt động đức tin, cùng một niềm tin về Đấng Thượng Đế Baha'i, trở thành những thành viên không chỉ đóng vai trò tín đồ của tổ chức tôn giáo mà còn đóng nhiều vai trò khác nhau đối với cộng đồng, quốc gia, dân tộc. Do đó, "cộng đồng Baha'i Việt Nam" có sự thống nhất không chỉ về đời sống đạo, việc chấp hành giáo lý, giáo luật Baha'i, thực hành các nghi lễ, kiêng kị, cũng như những chuẩn mực đạo đức mà tôn giáo Baha'i quy định.

Tương tự, khái niệm, "hoạt động xã hội" (activism) là hành vi cá nhân, tổ chức được diễn ra có mục đích để góp phần thay đổi xã hội theo chiều hướng tích cực. "Hoạt động xã hội" cũng là các hành vi thay đổi nhân loại, môi trường và tự nhiên mà thông qua đó thoả mãn những quyền lợi và nghĩa vụ đúng đắn cho các xã hội, con người vì chính bản thân con người phát triển theo định hướng bền vững và an toàn. 
Giả thiết nghiên cứu của bài viết là chức năng xã hội của cộng đồng Baha'i Việt Nam được thể hiện như thế nào trong đời sống tôn giáo trên địa bàn thủ đô Hà Nội, nổi bật là các lĩnh vực: giáo dục đạo đức, lối sống; từ thiện và an sinh xã hội; bảo vệ môi trường?

Hiện nay, chủ đề nghiên cứu về tôn giáo Baha'i nói chung và vai trò của Baha'i Việt Nam nói riêng còn khan hiếm, đặc biệt những nghiên cứu có tính chất chuyên sâu về một lĩnh vực hoạt động, hoặc đóng góp của tôn giáo này. Trong phạm vi bài viết này, tiếp cận vấn đề nghiên cứu từ các lý thuyết về chức năng xã hội của tôn giáo, tập trung vào một số cộng đồng tín đồ Baha'i Việt Nam dưới sự lãnh đạo của Hội đồng tinh thần Baha'i trên địa bàn thủ đô Hà Nội đã thể hiện được chức năng của mình trong các hoạt động xã hội như: vai trò của cộng đồng Baha'i đối với hoạt động giáo dục đạo đức, lối sống; tham gia từ thiện an sinh xã hội; tham gia bảo vệ môi trường.

\section{Phương pháp nghiên cứu}

Với mục đích nghiên cứu: phân tích chức năng xã hội của cộng đồng Baha'i Việt Nam trên địa bàn Hà Nội. Tác giả vận dụng nhiều phương pháp đặc thù, sự thống nhất giữa triết học và xã hội học tôn giáo: "Để nhận thức khoa học về chức năng xã hội của tôn giáo thì phương pháp thống nhất giữa sự phân tích về mặt nhận thức luận và phân tích về mặt xã hội học có ý nghĩa quan trọng, phá vỡ sự thống nhất đó sẽ dẫn tới xuyên tạc bản chất xã hội của tôn giáo hoặc đặc trưng nó một cách phiếm diện” (V. H. Nguyen, 1986, pp. 13-16).

Tác giả bài viết kết hợp các phương pháp triết học tôn giáo nhằm lý giải về nhận thức luận, xã hội học tôn giáo, đánh giá về chức năng của cộng đồng Baha'i đối với các hoạt động xã hội ở thủ đô Hà Nội thông qua các phương pháp nghiên cứu quan sát tham dự, mô tả, định lượng, định tính và nghiên cứu, phân tích tài liệu. Hai phương pháp được tác giả nhấn mạnh:

1) Phương pháp nghiên cứu định lượng qua khảo sát bảng hỏi trưng cầu ý kiến của 100 tín đồ đang sinh hoạt trong hai Hội đồng tinh thần Baha'i thủ đô Hà Nội là: Hội đồng Lê Đại Hành và Hội đồng Hữu Bằng. Từ số mẫu phiếu thu về hợp lệ được đưa vào xử lý trên chương trình SPSS 20.0 for Window đảm bảo tính khách quan về tần số, tần suất, tương quan, độ lệch biến và so sánh giữa hai nhóm theo giới tính, độ tuổi, thành phần xã hội ... Kết quả điều tra bảng trưng cầu ý kiến thông qua kiểm định Chi bình phương để có những kết luận so sánh mang ý nghĩa thống kê.

2) Phương pháp nghiên cứu tài liệu: Tài liệu quan trọng được tác giả sử dụng là Giáo lý Baha'i, Kinh Cầu nguyện Baha'i suy tưởng do Đức Baha'u'lla mặc khải và một số tài liệu nước ngoài liên quan đến đề tài Baha'i để tham khảo và xây dựng hệ thống khái niệm công cụ cho bài viết.

\section{Kết quả nghiên cứu và thảo luận}

\subsection{Kết quả nghiên cúu}

\subsubsection{Khái quát về tôn giáo Baha'i và Baha'i Việt Nam}

Thuật ngữ Baha'i theo tiếng Ả Rập là tin theo, noi theo, đi theo ánh sáng của Thượng đế. Baha'i xuất hiện tại $\mathrm{Ba}$ Tư (nay là Iran) vào năm 1863, theo phong trào Bab của Siyyid Ali Muhammad (1819 - 1850), được mệnh danh là Đáng Bab (Đấng Cửa mở), Mirza Husayn Ali (1817 - 1892), lấy danh hiệu là Baha'u'llah (hàm ý vinh quang của Thượng Đế) khởi xướng.

Phong trào Babi (tôn giáo Babi) của Ba Tư (1844 - 1852) do Siyyid Ali - Muhammad lãnh đạo nhằm mục đích hướng đến sự cải cách tôn giáo, khuyến khích mọi người hãy đóng cửa những niềm tin được coi là xưa cũ và hồ hởi chấp nhận "mở cửa" để đón nhận sự xuất hiện của một Đấng tổ thiêng liêng mới. Năm 1844, khi xã hội Ba tư rơi vào sự khủng hoảng về tâm linh 
và đạo đức. Trước tình cảnh đương thời, dưới triều đại nhà Qajar (1781 - 1925) với đầy rẫy bất công, nghèo đói, địa vị, thân phận người phụ nữ bị chà đạp, nhất là sau chiến tranh lần thứ hai giữa Nga - Ba Tư (1826 - 1828), các vùng Erivan, Nakhichevan, biển Caspi của Ba Tư phải nhượng quyền cho Nga đi lại buôn bán, giao thương tự do. Ngày 23 tháng 05, Siyyid'Ali Muhammad đã nổi dậy và khởi xướng, sáng lập tôn giáo mới theo tinh thần hướng thiện, nhân đạo, cải thiện địa vị người phụ nữ, đề cao giáo dục, mở mang dân trí, thúc đẩy khoa học phát triển để theo kịp các nước Châu Âu.

Phong trào canh tân tôn giáo này vừa xuất hiện, đã nhanh chóng lôi kéo nhiều người thuộc tầng lớp dân nghèo ra nhập, kéo dài suốt 09 năm (1844 - 1853). Đặc biệt giai đoạn, năm 1850 - 1853, phong trào bị nhà vua Nasser al-Din Shah Qajar cho quân đội đàn áp dã man. Các tín đồ bị ám sát và giết hại, lãnh tụ $\mathrm{Bab}$ bị bắt và tù đày. Tại thành phố Tabrriz vào ngày 09 tháng 07 năm 1850, Siyyid'Ali Muhammad bị mang ra tử hình. Sau khi lãnh tụ phong trào Bab qua đời, rất đông đảo người dân và tín đồ vẫn luôn tin tưởng vào những lời tiên đoán của Ông rằng sẽ có một vị sứ giả của Thượng Đế vĩ đại hơn Bab xuất hiện.

Quả thực, vào năm 1863, Mira Husayn Ali (1817 - 1892), là người kế vị Bab. Ông thuộc dòng dõi quý tộc $\mathrm{Ba}$ Tư, từ thuở thanh niên đã tin theo phong trào Babi, do vậy ông từ bỏ mọi địa xã hội và chính trị, dành toàn bộ tài sản để làm việc thiện như phân phát của cải, cứu giúp người nghèo đói, khó khăn và đau yếu tại ở Ba Tư. Khi trở thành người lãnh đạo Babi kế vị Bab, ông tuyên xưng là Baha'u'lah và là người sẽ dẫn dắt thế giới.

Trước tình cảnh phong trào Babi ngày càng phát triển dưới vai trò lãnh đạo của vị thủ lĩnh mới, chính quyền vua Vua Nasser al-Din Shah Qajar đẩy mạnh các hình thức đàn áp dã man và kiểm soát nhằm ngăn cản, tấn công và tiêu diệt tôn giáo mới Baha'i. Bất bình trước những hành động điên cuồng truy quét của chính quyền, tín đồ Baha'i chuyển từ hình thức tự vệ sang tấn công. Tháng 08 năm 1852, hai tín đồ Baha'i thực hiện mưu hại và ám sát vua $\mathrm{Ba}$ Tư. Sự kiện này khiến cho chính quyền có cớ tiếp tục dùng những biện pháp cứng rắn, khốc liệt và man rợ hơn đàn áp cộng đồng Baha'i. Do đó, thủ lĩnh Baha'u'llah bị chính quyền bắt giữ và đưa đi đày ải ở khắp nơi suốt 24 năm ròng rã, cuối cùng giam giữ tại $\mathrm{Akka} \mathrm{(thuộc} \mathrm{Israel} \mathrm{ngày} \mathrm{nay).} \mathrm{Thời}$ gian ở Akka và Haifa, nhận thấy đây là hai thành phố có nhiều điều kiện để tiếp tục sự nghiệp phục hưng phong trào Babi, Baha'u'llah đã âm thầm liên hệ với tín đồ ở bên ngoài và cho xây dựng ở đây thành Trung tâm Tâm linh và Quản trị của Baha’i.

Năm 1892, Baha'u'llah sau thời gian dài bị đày ải, tra tấn và giam cầm, ông qua đời và được chính quyền mai táng tại Haifa (Israel). Nơi chôn cất Baha'u'llah đã nhanh chóng được những người theo Baha'i ở Haifa cho xây dựng thành Lăng mộ và xem là chốn thiêng liêng, đồng thời cũng là trung tâm hành hương của tín đồ Baha'i.

Sau khi Baha'u'llah mấy, người kế vị tiếp tục sứ mệnh lãnh đạo cộng đồng Baha’i là Abbas Effendi (1844 - 1921) là con trai trưởng của ông. Abbas Effendi trên cương vị lãnh đạo mới của Baha'i đã tuyên xưng là Abdu'1 Baha (theo tiếng Ả rập là phục tùng Thượng đế).

Do Abdu' 1 Baha không có con trai, nên sau khi mất, người kế nhiệm là cháu ngoại của ông là Shohoghi Effend (1897 - 1957) được chọn giữ vị trí thủ lĩnh tinh thần và Giáo hộ của cộng đồng Baha'i. Shoghi- Effendi mất thì nền quản trị đổi thành Hội đồng Quốc tế.

Qua các thời kỳ truyền bá, phát triển đến năm 1921, số lượng tín đồ Baha'i có có khoảng trên dưới 01 triệu phân bố tại 35 quốc gia; năm 1990, khoảng gần 4.9 triệu tín đồ ở 214 quốc gia; năm 2000, khoảng hơn 05 triệu tín đồ ở 235 quốc gia; năm 2007, hơn 6.2 triệu tín đồ; năm 2010 khoảng 07 triệu tín đồ; năm 2017 có khoảng 07 triệu tín đồ ở 330 quốc gia và vùng lãnh thổ (X. 
T. Nguyen, 2020, pp. 159-164).

Baha'i trong lịch sử hình thành và phát triển của mình cũng có những ảnh hưởng nhất định trong cộng đồng quốc tế. Năm 1948, Liên Hiệp Quốc công nhận cộng đồng Baha'i quốc tế với tư cách là tổ chức phi chính phủ. Năm 1970, Baha’i giữ trọng trách mới với vai trò tư vấn tại Hội đồng kinh tế - xã hội Liên hợp quốc (Economic and Social Council - ECOSOC); Chủ tịch các Uỷ ban của Tổ chức phi Chính phủ tại Liên Hợp Quốc. Bên cạnh đó, cộng đồng Baha'i quốc tế trong phạm vi quyền hạn và trách nhiệm của mình đã góp phần quan trọng đối với các tổ chức trong hệ thống Liên hợp quốc: Tổ chức y tế thế giới (World Health Organization - WHO), Chương trình môi trường của Liên hợp quốc (UNEP), Quỹ trẻ em của Liên hợp quốc (United Nations International Children's Emergency Fund - UNICEF). Bằng những cô gắng và nỗ lực không ngừng, cống hiến và dấn thân vì sự tiến bộ, hoà bình, bình đằng giới, năm 1991, Cộng đồng Baha'i quốc tế được Quỹ phát triển vì Phụ nữ của Liên hợp quốc (Fonds de développement des Nations unies pour la femme - UNIFEM) lựa chọn triển khai chương trình tài trợ dự án sử dụng các phương tiện truyền thông nhằm thúc đẩy sự tiến bộ cho phụ nữ trên toàn thế giới.

Toàn bộ hệ thống Kinh sách của Baha'i được truyền dạy bởi những người sáng lập, Kinh thánh Kitabia Qdas của Baha'u'llah biên soạn được các tín đồ xem là thiêng liêng nhất. Kinh sách Baha'i biên soạn thành 150 bộ và dịch ra 800 ngôn ngữ khác nhau. Nội dung kinh sách, toàn bộ giáo lý và giáo luật của Baha'i là sự tổng hợp nhiều giáo lý của nhiều tôn giáo: Phật giáo, Kitô giáo, Ấn Độ giáo, Bái Hoả giáo, ... và nhất là Islam. Trong quá trình tiếp thu, pha trộng nội dung triết thuyết của những tôn giáo này, Baha'i có sự chọn lọc, sửa đổi theo hướng đơn giản hơn nhằm phù hợp với nhu cầu tâm linh thời đại mới.

Giáo lý Baha'i thờ phụng Thượng Đế và chủ trương hướng con người tới đời sống nhân hoà, bỏ qua mọi sự xung đột dân tộc, sắc tộc và tôn giáo trên tinh thần đề cao thân ái, chia sẻ và đối thoại, xoá đói, giảm nghèo và bất bình đẳng xã hội. Đề cao các vấn luân lý đạo đức, bảo vệ môi trường, đề cao bình đẳng, đặt trọng tâm xây dựng giáo dục và đào tạo cộng đồng. Đồng thời, Baha'i xem các tôn giáo khác tiền đề khai mở cho chân lý tâm linh, mỗi tôn giáo là một chương sách trong tập sách của Thượng Đế, còn Baha’i đóng vai trò xương sống của cuốn sách. Các Đấng như Adam, Noah, Krishna, Moses, Zoroaster, Buddha, Je'sus, Muhammad, Đức Bab, Đức Baha'u'llah, đề là những nhà tiên tri được Thượng Đế lựa chọn và được Ngài phái xuống trần gian theo các mốc sự kiện thời gian, không gian khác nhau để cứu vớt nhân loại. Mỗi sứ giả của Thượng Đế đều có chu kỳ riêng. Đặc biệt, chu kỳ của Baha'u'llah là một nghìn năm. Giáo lý Baha'i còn nhìn nhận sự hoà hợp cần thiết giữa khoa học và tôn giáo. Cấm chế độ nô lệ, không thực hiện ẩn tu, khất thực, xuất thế, tuyệt đối loại bỏ rượu, chất kích thích và ma tuý, ... đề cao trách nhiệm sống và làm việc theo hiến pháp, pháp luật của nhà nước.

Baha'i quy định về giáo luật, yêu cầu tín đồ phải đọc thánh kinh và cầu nguyện hàng ngày các buổi sáng, nghi thức cầu nguyện tại gia và chỉ gặp nhau vào ngày lễ.

Đạo Baha'i có 12 Thánh lễ được cử hành hàng năm là: Lễ Naw-Ruz ngày 21/03 (còn gọi tết Baha'i); Lễ Rid Van thứ nhất (21 tháng 04, ngày tuyên ngôn của Baha'u'llah). Lê̂ Rid Van thứ chín (ngày 29 tháng 04); Lễ Rid Van thứ mười hai (Ngày 02 tháng 05); Lễ Đức Bab tuyên ngôn (ngày 23 tháng 05); Lễ Baha'u'llah về trời (29 tháng 05); Lễ tử đạo của Đức Bab (ngày 09 tháng 07); Giáng sinh Đức Bab (ngày 20 tháng 10); Lễ giáng sinh Đức Baha'u'llah (ngày 12 tháng 11); Lễ giao ước (ngày 26 tháng 11); Lễ thăng về trời Abdul Baha (ngày 28 tháng 11). Trong các ngày Thánh lê̂ đó, ngày Ridvan thứ nhất (21 tháng 04) là đối với tín đồ Baha’i là quan trọng nhất. 
Bên cạnh đó, người theo Baha'i trừ những trường hợp đặc biệt qui định phải giữ trai giới liên tục trong 19 ngày/năm, (02 đến ngày 21 tháng 03). Suốt những ngày trai giới, ban ngày tín đồ nhịn ăn uống, (khi mặt trời bắt đầu mọc cho đến lúc lặn), họ ăn uống lúc tối sau khi mặt trời lặn. Qui định này nhằm giúp tín đồ dùng toàn tâm trí, thời gian ban ngày để suy tưởng và cầu nguyện, củng cố đức tin.

Baha'i có đại diện quản lý tại các địa phương thực hiện toàn bộ hoạt động, sinh hoạt là Hội đồng tinh thần địa phương. Tổ chức này bao gồm 09 thành viên được tín nhiệm thông qua bầu cử bằng phiếu kín hàng năm.

Sự phân cấp và phân quyền lãnh đạo trong cộng đồng Baha'i mang tính toàn cầu, được chia thành ba cấp. Cấp cao nhất là Hội đồng Tinh thần quốc tế (Toà Công lý quốc tế); tiếp đến là Hội đồng Tinh thần quốc gia và cuối cùng là Hội đồng Tinh thần địa phương. Baha'i có Trung tâm quốc tế tại Haifa (Israen). Hiện nay, Baha'i có nhiều đền thờ, trong đó 08 đền thờ lớn cấp châu lục đặt tại Mỹ, Úc, Đức, Chile, Uganda, Ân Độ, Samoa, Panama.

Baha'i du nhập vào Việt Nam những năm 1920, nửa đầu thế kỷ XX, nhưng không phát triển được. "Năm 1954, Baha'i được bà Shirin Fozdar từ Ấn Độ sang, bà là Uỷ viên truyền giáo của Hội đồng Tinh thần Quốc gia Baha'i Ân Độ" (Toan Anh, 1972, p. 109). Tháng 04 năm 1955, tại Sài Gòn, Hội đồng tinh thần Baha'i đầu tiên thành lập. Trước 30 tháng 04 năm 1975, Baha'i Việt Nam, có 687 Hội đồng tinh thần địa phương, hoạt động chủ yếu ở miền Nam. “Baha'i có nhiều hoạt động nổi bật trước đây như tổ chức "Ngày tôn giáo toàn cầu” hàng năm kể từ năm 1962. Vào ngày này, theo lời mời của Baha'i, đại diện các tôn giáo khác: Phật giáo, Công giáo, Islam, ... sẽ đến tham dự và cùng nhau thảo luận các vấn đề liên tôn, thống nhất, hoà hợp tôn giáo trong xã hội. Trong khoảng thời gian từ năm 1964 đến năm 1975, Hội đồng tinh thần Baha'i Quốc gia Việt Nam đã nhiều lần được tham gia bầu Hội đồng tinh thần Quốc tế" (X. T. Nguyen, 2020, pp. 159-164).

Sau giải phóng miền Nam 1975, Baha'i giảm dần các hoạt động của mình. Riêng Thành phố Hồ Chí Minh, cộng đồng Baha'i vẫn tổ chức một số ngày lễ của đạo. Hơn nữa, vì chưa được công nhận pháp nhân, nên các tín đồ Baha'i chỉ tổ chức cầu nguyện thực hành giáo lý tại gia đình. Trong những năm gần đây, với sự nỗ lực và những cố gắng của mình, cùng với sự cởi mở trong đường lối, pháp luật của Đảng và Nhà nước về tôn giáo, Baha'i đã được công nhận tổ chức và hoạt động ở nhiều tỉnh thành phố lớn như Hà Nội, Vĩnh Phúc, Hải Phòng, Nam Định, Phú Thọ, Sơn La, Hoà Bình, Hà Tây (nay là Hà Nội), Bắc Giang, Sơn La ... (X. T. Nguyen, 2020, p. $164) \ldots$

Qua nhiều cố gắng nỗ lực để hoàn thiện và phát triển, “tháng 03 năm 2007, Chính phủ Việt Nam cấp chứng nhận đăng ký hoạt động tôn giáo với tê gọi Cộng đồng tôn giáo Baha’i Việt Nam, được điều hành bởi Hội đồng tinh thần tôn giáo Baha'i Việt Nam. Ngày 14 tháng 07 năm 2008, Ban Tôn giáo Chính phủ đã ký quyết định công nhận tổ chức Cộng đồng tôn giáo Baha’i Việt Nam" (Hong Ly, 2008, pp. 5, 28).

Trong năm 2008 đến nay, Baha’i Việt Nam đã trải qua 12 kỳ đại hội toàn quốc và đại hội Hội đồng tinh thần Baha'i các địa phương. Hiện nay, tín đồ của Baha'i Việt Nam khoảng hơn 08 nghìn ở 45 tỉnh, thành phố trong cả nước. Những địa phương tập trung đông tín đồ cộng đồng tôn giáo Baha'i ở nước ta hiện nay là Hà Nội, Đà Nẵng, Quảng Nam, Cần Thơ, Thành phố Hồ Chí Minh, Hậu Giang, Sóc Trăng, Kiên Giang, Ninh Thuận, Gia Lai, ...

4.1.2. Hội đồng tinh thần Baha'i Lê Đại Hành và Hội đồng tinh thần Baha'i Hưu Bằng tại thủ đô Hà Nội trên các phưong diện hoạt động giáo dục đạo đức, lối sống; tham gia tù thiện 
an sinh xã hôi; tham gia bảo vệ môi trương

Baha'i xuất hiện ở thủ đô Hà Nội khoảng đầu thế kỷ XX. Năm 1990, một số tín hữu Baha'i từ Thành phố Hồ Chí Minh, Đà Nẵng di chuyển ra Hà Nội và bắt đầu truyền đạo. Khi mới xuất hiện, Baha'i phát triển tín đồ rất chậm. Đến giai đoạn những năm 2000, hoạt động truyền giáo vẫn gặp nhiều trở ngại do gặp phải những vấn đề pháp lý và sự khác biệt trong niềm tin tôn giáo Baha'i so với những tôn giáo có truyền thống lịch sử lâu đời tại thủ đô. Do vậy, số người đứng vững được với đức tin Baha'i không nhiều. "Năm 2007, khi Baha'i chính thức được Chính phủ nước ta chứng nhận đăng ký hoạt động và Ban Tôn giáo Chính phủ ký quyết định công nhận tổ chức Cộng đồng tôn giáo Baha'i Việt Nam năm 2008” (Hong Ly, 2008, pp. 5, 28) thì Công đồng Baha'i Hà Nội được thành lập chính thức và đi vào hoạt động với hai Hội đồng tinh thần là: Hội đồng tinh thần Baha'i Lê Đại Hành và Hội đồng tinh thần Baha'í Hữu Bằng. Từ đó đến nay, theo thống kê của Ban tôn giáo Hà Nội, tính đến năm 2020 (Ban Tôn Giáo, Sở Nội vụ Hà Nội, 2020), hai Hội đồng tinh thần Baha'i địa phương tại thủ đô Hà Nội luôn cố gắng với tinh thần nhập thế, hoà hợp tôn giáo để có thể đóng góp một cách hiệu quả nhất cho những hoạt động cộng đồng. Số lượng tín đồ hiện nay có khoảng gần 450 người với 02 chức sắc và 10 chức việc. Sinh hoạt hai Hội đồng tinh thần Baha'i địa phương tại Hà Nội không nhất thiết cố định tại một địa điểm mà có thể do các tín hữu cho mượn nhà hoặc đi thuê, tùy vào hoàn cảnh cụ thể và tình hình kinh tế của họ. Thành phần tín đồ của hai cộng đồng tinh thần Baha'i địa phương tại Hà Nội tương đối đa dạng. Hiện nay, có xu hướng gia tăng tỉ lệ những người có học vấn, trí thức. Trong hai Hội đồng tinh thần Baha'i địa phương tại Hà Nội thì Hội đồng tinh thần Baha'i Hữu Bằng chiếm số lượng tín đồ tập trung đông hơn. Các tín đồ tham gia vào nghiên cứu này, có nhiều người hiện là tín đồ của cả hai Hội đồng tinh thần Baha'i địa phương tại Hà Nội.

\section{Một là, vai trò của cộng đồng Baha'i đối với hoạt động giáo dục đạo đức, lối sống}

Giáo dục đạo đức, lối sống cho tín đồ và con em của những người theo tôn giáo Baha’i luôn là nhiệm vụ cần thiết được Cộng đồng Baha'i Hà Nội quán triệt. Chính vì vậy hàng năm, cả hai Hội đồng tinh thần Baha'i địa phương Hà Nội đều tổ chức các lớp học giáo lý và các hoạt động xây dựng cộng đồng như:

Nhóm cầu nguyện, có sự tham gia của tín đồ Baha'i Hà Nội vào các buổi tối hoặc các ngày cuối tuần theo lịch sinh hoạt định kỳ tại các điểm nhóm. Khi được hỏi về ý nghĩa của hoạt động này, tín đồ Nguyễn Văn M (điểm nhóm Hội đồng tinh thần Baha'i Lê Đại Hành) cho biết:

"Đối với tín đồ Baha'i, cầu nguyện là thức ăn của linh hồn, là sụ thông công giữa con người với Thượng Đế, nhờ đó linh hồn phát triển và là nguyên nhân của mọi điều thiện nảy sinh. Trong mồi buổi cầu nguyện này, nhóm Hội đồng tinh thần Baha'i Lê Đại Hành chúng tôi thuờng chia thành 03 nhóm nhỏ sinh hoạt tại nhiều nơi và có khoảng0 đến 40 người tham dư, tuỳ thời điểm" [Phỏng vấn thực hiện lúc 20h ngày 19/12/2020, tại điểm sinh hoạt Lê Đại Hành].

Người Baha'i cho rằng "Linh hồn con người cần phải được nuôi duõ̃ng truớc hết. Và sự cầu nguyện có thể cung cấp tốt nhất thức ăn tâm linh này. Như Đức Baha'u'llah tiên liẹu, các Giáo luật và các Co cấu chỉ thực sụ phát huy hiệu lục khi đời sống nội tâm chúng ta biến cải và hoàn thiện. Bà̀ng không tôn giáo sẽ thoái hoá thành một tổ chức suông, và trở thành một vật chết" (Hội đồng tinh thần Baha'i Việt Nam, 1991, p. 238).

Việc tổ chức các nhóm cầu nguyện để mọi người thuộc mọi tầng lớp xã hội, thuộc mọi tôn giáo cùng ngồi lại với nhau để cầu nguyện Lời của Thượng Đế duy nhất được mặc khải qua các Thánh Kinh, nhờ sự quy tụ này, sự thống nhất và tình thương sẽ nảy sinh và phát triển dồi dào trong tâm hồn con người cũng như mỗi tín đồ tham dự, vừa giáo dục đạo đức, lối sống và tình yêu thương đối với nhân loại, tha nhân giữa cuộc đời bộn bề khổ đau và bận rộn trong cuộc sống hiện đại ngày nay theo tín đồ Baha'i là vô cùng quan trọng. 
Bên cạnh đó, cũng theo các tín đồ Baha'i đang sinh hoạt trong hai nhóm Hội đồng tinh thần Baha'i Lê Đại Hành và Hội đồng tinh thần Baha'í Hữu Bằng tại Hà Nội, các hoạt động tổ chức theo nhóm học tập cũng được duy trì thường xuyên. Mức độ tham gia của các tín đồ theo tần suất như bảng dưới đây:

\section{Bảng 1}

Mức độ tham gia các nhóm học tập của tín đồ Cộng đồng Baha’i tại Hà Nội

\begin{tabular}{|l|c|c|c|c|}
\hline \multicolumn{1}{|c|}{ Mức độ tham gia nhóm học tập (tỉ lẹ \%) } & $\begin{array}{c}\text { Thường } \\
\text { xuyên }\end{array}$ & $\begin{array}{c}\text { Thỉnh } \\
\text { thoảng }\end{array}$ & $\begin{array}{c}\text { Hiếm } \\
\text { khi }\end{array}$ & $\begin{array}{c}\text { Không } \\
\text { tham gia }\end{array}$ \\
\hline Hội đồng tinh thần Baha'i Lê Đại Hành & 45.0 & 35.0 & 15.0 & 5.0 \\
\hline và Hội đồng tinh thần Baha'í Hữu Bằng & 35.0 & 25.0 & 30 & 10.0 \\
\hline
\end{tabular}

Nguồn: Theo kết quả khảo sát của tác giả (2019 - 2020)

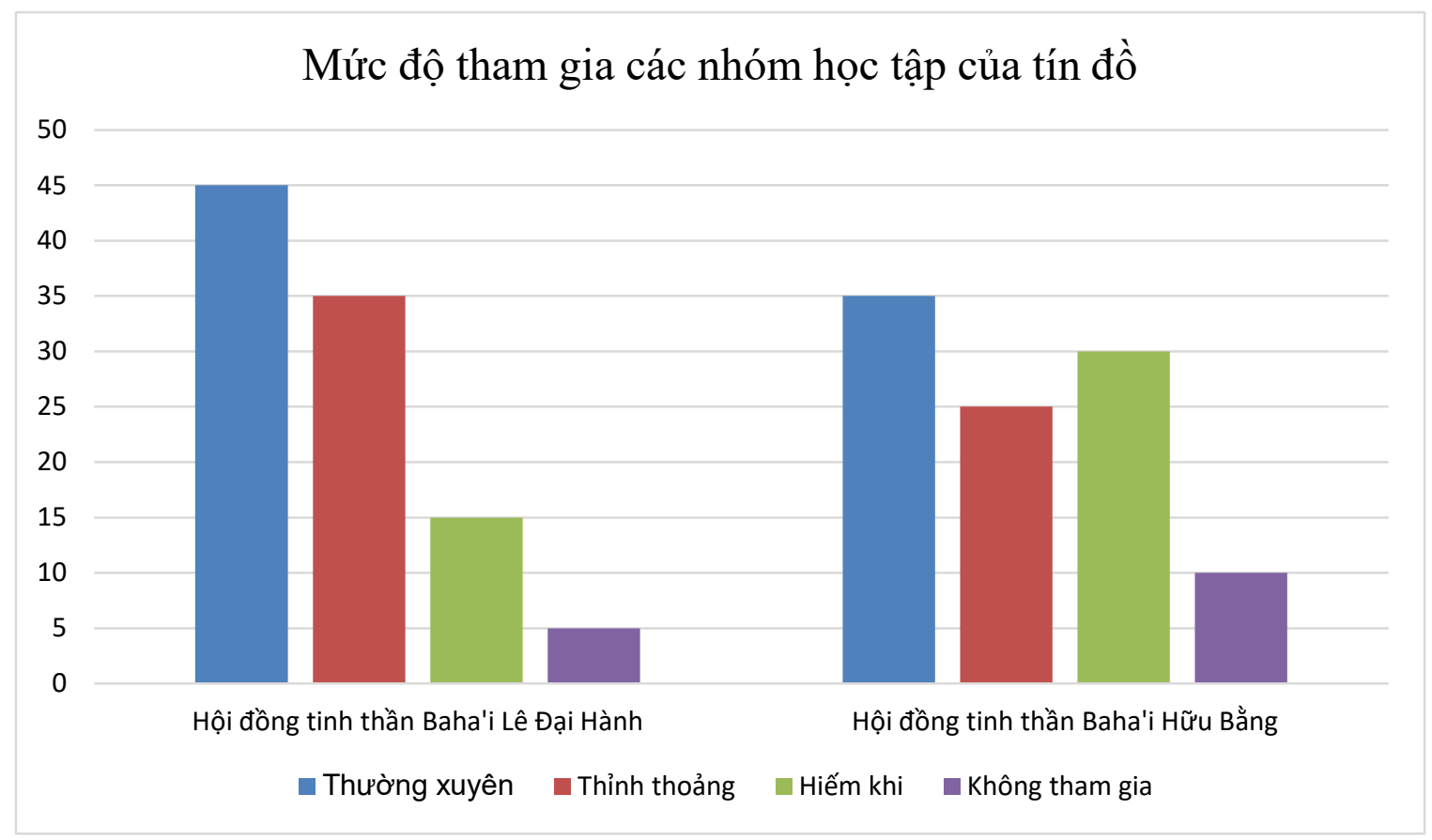

Hình 1. Mức độ tham gia các nhóm học tập của tín đồ

Qua bảng so sánh giữa hai nhóm Hội đồng tinh thần Baha'i địa phương cho thấy tỉ lệ tín đồ thường xuyên tham gia các nhóm học tập vẫn chiếm ưu thế (Hội đồng tinh thần Baha'i Lê Đại Hành là 45.0\%; Hữu Bằng là 35.0\%). Điều này cho thấy, đối với tín đồ Baha'i các hoạt động học tập cộng đồng có vai trò quan trọng. Bởi theo như phát biểu của tín đồ Vũ Văn $\mathrm{X}$ cho rằng: "Đối với một người là tín đồ Baha'i thì không chỉ ghi danh là đủ mà còn phái luôn luôn học hỏi qua giáo lý của Đức Baha'u'llah đã mặc khải cho thời đại nhân loại trương thành ngày nay để có thể hoàn thành nghĩa vu tâm linh của người Baha'i là phụng sụ người khác, phụng sự nhân loại với tình yêu vị tha, vô hạn. Vì vậy, văn hoá Baha'i có thể nói là văn hoá học tập." [Phỏng vấn của tác giả lúc 19h00' ngày 15 tháng 10 năm 2019, tại điểm nhóm sinh hoạt Baha'i Hữu Bằng, Hà Nội]. Chính vì ý thức được điều đó, cho nên tín đồ Baha'i luôn luôn học hỏi để việc phụng sự ngày một hiệu quả hơn. Cộng đồng Baha'i Việt Nam nói chung và Cộng đồng Baha'i Hà Nội nói riêng luôn tổ chức các nhóm học tập một cách có hệ thống trên nhiều địa phương và quán triệt đến từng điểm nhóm, từng Hội đồng tinh thần Baha'i địa phương. Đây cũng là cơ hội để mọi người Baha'i cũng như không phải Baha'i cùng chia sẻ Sứ điệp hiếu sinh của Thượng Đế nhằm giúp tiếp nhận sự biến cải tâm linh sâu xa, giúp xây dựng một xã hội hướng thiện và một thế giới hoà bình. 
Bên cạnh đó, đối với cộng đồng Baha'i Việt Nam nói chung, cộng đồng Baha’i Hà Nội nói riêng, việc giáo dục Thiếu nhi, thiếu niên và thanh niên cũng là hoạt động vô cùng quan trọng. Bởi theo như lời của Đức Abdul Baha thì: "Cộng đồng ... ngày và đêm phải tìm cách và cố gắng hoàn thành việc giáo dục con người với nhiệt tình và nô̂ lực cao nhất, khiến con nguò̀i đạt tiến bộ mối ngày, càng gia bội khoa học và kiến thức, thủ đắc đức hạnh, đạt tới đạo đức cao và tránh tật xấu, nhu thế thì tọi ác không thể xẩy ra nũa . Hiện giờ điều ngược lại đang thịnh hành; cộng đồng luôn nghĩ tới việc áp đặt luật hình sự, chuẩn bị phuơng tiện để trùng phạt, công cu để xư tư và gia hình, nhũng nơi để giam cầm và lưu đày ..." ( Hội đồng tinh thần Baha'i Việt Nam, 2018a, p. 271).

Người Baha'i tin rằng điều thông qua giáo dục cộng đồng nhằm mục đích thành tựu cho tín đồ các giá trị đạo đức như lương thiện, tin cậy, bao dung, can đảm, kính trọng, lịch sự, rộng lượng, kiên nhẫn, siêng năng, ... cũng như việc học tập và nghiên cứu khoa học, định hướng thẩm mĩ nghệ thuật để tầng lớp thanh thiếu niên, nhi đồng, con em của các tín hữu Baha'i sẽ trở thành một thế hệ mới tốt đẹp của xã hội. Việc giáo dục đặc biệt giúp những người trẻ có tâm lý vững vàng, chín chắn, trưởng thành hơn ở vào tuổi thanh thiếu niên. Trong đó, theo các tín đồ Baha'i việc giáo dục các bé gái là quan trọng hơn cả. Trần Văn $\mathrm{B}$ (điểm nhóm Hội đồng tinh thần Baha'i Hữu Bằng) cho rằng: "Việc giáo duc các bé gái được xem là có tầm quan trọng đặc biệt, vì nhũng nguời me là nguời thầy đầu tiên của một thế hệ tiếp theo. Nhu vậy, nếu trong một gia đình không đủ khả năng tài chính để cho các con đi học, thi phải dành uu tiên cho bé gái." [Phỏng vấn của tác giả, lúc 19h00', ngày 10 tháng 08 năm 2019, tại điểm nhóm sinh hoạt Baha’i Hữu Bằng].

Chính Đức Abdul Baha cũng khẳng định: "Vấn đề dạy dỗ thiếu nhi và chăm sóc trẻ em mồ côi là vô cùng quan trọng, nhung quan trọng hơn hết là giáo dục các cháu gái, vì một ngày kia các cháu gái này sẽ trở thành những bà mẹ, và nguời me là người thầy đầu tiên của đứa con. Nguời me dạy co nhu thế nào, con sẽ trở nên nhu thế đó, và kết quả của sư dạy dồ đầu tiên này sẽ tồn tại nơi cá nhân suốt cả đời, và điều đó thật khó làm thay đổi được. Và nếu chính người mẹ là u tối, thiếu dạy dỗ, thì làm sao người ấy dạy con được? Bởi vậy, điều rõ ràng là việc giáo dục các bé gái tạo hậu quả lón lao hơn nhiều so với việc giáo dục các bé trai. Sụ kiện này là cục kỳ quan trọng, và vấn đề cần phải được lư ý với nhiệt tâm và với lòng tận tuy tột cùng" (Hội đồng tinh thần Baha'i Việt Nam, 2018b, para. 635).

Trong các gia đình Baha’i cũng luôn giáo dục con cái của họ chịu trách nhiệm với chính mình kèm theo đó là sự giáo dục đức tin vô cùng quan trọng. Theo tìm hiểu thông qua một tín đồ Baha'i Trần Văn X, 45 tuổi, Hội đồng tinh thần Lê Đại Hành cho rằng: "Tré em trong gia đình có cha, me là Baha'i được soi sáng bởi giáo lý Baha'i tù̀ cha mẹ. Khi trẻ em 15 tuổi thì các cháu tụ đảm đương trách nhiệm cho chính mình. Một người khi chấp nhận Đức Baha'u'llah là Đấng Sứ giả của Thuợng Đế thì sẽ tuyên xung tại Hội đồng Tinh thần Địa phuoong gần nhất và trở thành tín đồ của cộng đồng Baha'i không phải qua một lễ nghi nào." [Phỏng vấn của tác giả, lúc 19h00', ngày 12 tháng 09 năm 2019, tại điểm nhóm sinh hoạt Baha’i Lê Đại Hành].

Toà công lý Quốc tế Baha'i cũng khẳng định: "Người tuyên xung tín đồ không cần biết tất cả các bằng chứng, lịch sư, giáo luật và các nguyên lý của Chính Đạo, nhũng trong quá trình tuyên xung, ngoài việc tiếp nhận tia sáng đức tin, ho phải hiểu biết một cách co bản về các Nhân vật Trung tâm của Chính Đạo, cũng nhu sụ tồn tại của các giáo luật mà ho phải tuân theo và một nền quản trị mà ho phải phục tùng" (Toà Công lý Quốc tế, 2014, para. 185).

Nếu một tín đồ Baha'i không còn tin tưởng vào Đức Baha'u'llah và không muốn sinh hoạt trong cộng đồng thì người ấy được tự do hành động theo ý mình và thông báo cho Hội đồng Tinh thần Địa phương nhằm xoá tên khỏi danh sách bầu cử. 
Trong hôn nhân và gia đình, cộng đồng tinh thần Baha'i Việt Nam nói chung và cộng đồng Baha'i Hà Nội nói riêng luôn quán triệt tín đồ phải tuân thủ hiến pháp và pháp luật, mà cụ thể là Luật hôn nhân gia đình. Người theo Baha'i cho rằng, hôn nhân phải chấp hành nghiêm chỉnh quy định một vợ một chồng. Tín đồ Baha'i được tự do cưới vợ, lấy chồng, không phân biệt tôn giáo, tín ngưỡng. Những quan niệm về hôn nhân hết sức cởi mở, dễ dàng chấp nhận hôn nhân liên tôn mà không có một rào cản nào. Đức Abdul baha nói: "Hôn nhân là sự tận hiến của hai bên cho nhau và là sự gắn bó cả trí tuệ và tâm hồn với nhau. Tuy nhiên, mối bên phải hết sức lưu ý tìm biết tính cách của nhau, để cho giao wớc bền chặt giữa hai bên sẽ là mối liên hệ đời đời. Mục đích của đôi bên phải nhu thế này: là trở thành đồng chí và bạn đời đầy yêu thương, và trở nên là một với nhau bây giờ và mãi mãi ...

Hôn nhân thực sự của người Baha'i là nhu thế này, rằng chồng và vợ phải nên là một về vật chất và tinh thần, rằng ho có thể mãi mãi giúp nâng cao đời sống tâm linh của nhau, và có thể hiệp nhất đời đời qua tất cả các thế giới của Thượng Đế. Đây là hôn nhân Baha 'i" (Hội đồng tinh thần Tôn giáo Baha'i Việt Nam, 2016, p. 118).

Khi được hỏi về hôn nhân Baha'i, một tín đồ Hội đồng tinh thần Baha'i Lê Đại Hành, Phạm Thị V. cho rằng: "Hôn nhân Baha'i truớc hết cũng giống nhu hôn nhân theo quy định của pháp luật, đó phải là sụ tụ đồng ý của chính hai người nam, nũu, sau đó là sự cho phép của cha me đôi bên. Hôn lễ Baha'i cuñng đơn giản lắm, phần cốt yếu quan trọng của buổi lê̂ là cô dâu và chú rể đọc câu tuyên hứa "Quả thật, tất cả chúng con đều vâng phục ý chí Thượng Đế," truớc hai nhân chứng do Hội đồng tinh thần chi định. Sau đó sẽ đự̛c Hội đồng tinh thần Địa phuơng cấp giấy chứng nhận hôn thú, bên cạnh giấy chưng nhận hôn thú của chính quyền sở tại. Hôn nhân cũng nhu các luật xã hội khác, tín đồ Baha'i tuân theo luật dân sự của đất nước minh" [Phỏng vấn lúc 18h00, ngày 27 tháng 08 năm 2020, tại điểm sinh hoạt Lê Đại Hành].

Trong quan niệm về ly hôn, giới luật Baha'i cho phép ly hôn nhưng cực lực can ngăn nếu có sự bất hoà xẩy ra giữa cặp vợ chồng, hai người phải hội ý với Hội đồng tinh thần Địa phương để hoà giải. Trường hợp hoà giải không thành thì hai vợ chồng phải sống ly thân một năm. Trong năm thử thách này họ tìm mọi cách để hoà giải, và nếu hết một năm kiên nhẫn chờ đợi mà vẫn không hoà giải được thì việc ly hôn được tiến hành. Về ly hôn tín đồ Baha'i cũng tuân theo luật dân sự của đất nước.

Bên cạnh đó, cộng đồng Baha’i Hà Nội còn tham gia nhiều hoạt động phụng sự như tham gia từ thiện xã hội, dấn thân và hành động xã hội. Bởi đối với tín đồ Baha’i:

"Điều quan trọng đối với mọi nguời là nhận biết rằng giá trị của việc dấn thân vào hành động xã hội và hội thảo công cộng không phải để được xét đoán bởi khả năng nâng số người tuyên xưng. Dù nhũung nỗ lực trong hai lĩnh vực hoạt động này có thể đưa tới sự gia tăng tầm cõ của cộng đồng Baha'i, chúng ta làm không phải vì muc đích này" (Hội đồng tinh thần Baha'i Việt Nam, 2010, para. 31).

Tích cực đóng góp cho những sinh hoạt cộng đồng của người Baha’i, nhằm hình thành năng lực cho tín đồ trong việc phụng sự nhân loại. Các hoạt động phụng sự cho mọi người của Baha'i có ý nghĩa giúp tín đồ có thể tự đảm trách các hoạt động cộng đồng, cải thiện điều kiện tâm linh lẫn vật chất quanh mình. Chức việc Phan Văn B (Hội đồng tinh thần Baha'i Hữu Bằng) phát biểu: "Người Baha'i tin rằng thế giới loài người nhu một gia đình nhân loại. Nên, dù ở mức độ cá nhân hay cộng đồng, người Baha'i cũng có thể đóng góp nhũng ý tuởng phụng sự xã hộ qua nhiều hình thức nhur nhạc hoạ, kịch nghệ, văn tho; ... hoạc các lĩnh vục nhu giáo dục bình đẳng giới, giáo dục thống nhất chủng tộc, giáo dục đạo đức cho thiếu nhi và người lớn ... Nhìn chung, ở mọi khía cạh trong cuộc sống người Baha'i tích cực tham gia vào dựa trên cảm hứng lời dạy của Đức Baha'u'llah: Làm việc trong mục đích phụng sụ nhân loại là hình thức thò̀ 
phụng cao cả nhất”' [Phỏng vấn của tác giả, lúc 19h00', ngày 10 tháng 08 năm 2019, tại điểm nhóm sinh hoạt Baha'i Hữu Bằng].

Với quan niệm làm theo lời dạy của Đức Baha'u'llah, cộng đồng tinh thần Baha'i Hà Nội quán triệt: "Thế giới này có thể tốt đẹp hơn nhờ nhũng hành động cao quý và trong sạch, nhò̀ nhũng hạnh kiểm đoan chính và đáng ca ngợi" (Hội đồng tinh thần Baha'i Việt Nam, 2018a, pp. 24-25).

Người Baha'i được dạy về hạnh chính trực, trung thành và không thành kiến là phương châm sống của một tín đồ với đời tận hiến và phụng sự. Các phương pháp và cách thức phụng sự vươn ra cộng đồng của Baha'i góp phần lan toả tinh thần cống hiến xã hội đến mọi người, mọi tầng lớp xã hội, không phân biệt tôn giáo, sắc tộc hay chủng tộc, giới tính hay địa vị xã hội theo quan điểm văn minh, tiến bộ và bình đẳng.

\section{Hai là, vai trò của cộng đồng Baha'i đối với hoạt động bảo vệ môi trường}

Đức Baha'u'llah chỉ dạy các tín đồ Baha'i: "Nền văn minh thuờng được ca tụng bởi nhũng bậc thiên tài về khoa học và nghệ thuật. Nếu để vuợt khỏi giới hạn của sụ trung dung, thì sẽ đem điều ác lớn lao đến cho loài người. Đó là điều cảnh báo các ngươ bởi Ngài là Đấng Toàn tri. Nếu bị đẩy tới chỗ thái quá, nền văn minh sẽ cho thấy nó là nguồn gốc phong phú của điều ác, cũng nhu nó tùng là nguồn gốc của điều thiện khi giữ trong giới hạn của sụ trung dung ... Đã sắp đến ngày lưa lầm lạc sẽ thiêu rụi các đô thị ..." (Hội đồng tinh thần Baha'i Việt Nam, 2018b, p. 343).

Góp phần tạo dựng tinh thần bảo vệ trái đất, vì một hành tinh xanh, sạch, đẹp cho nhân loại, các tín đồ Baha'i có nhiều hoạt động bảo vệ môi trường sinh thái tại khu dân cư. Cả hai cộng đồng tinh thần Baha'i Hà Nội, cũng tiến hành nhiều hoạt động giữ gìn môi trường, cảnh quan đường phố, khu dân cư, tổ chức nhiều phong trào: Trồng cây vì màu xanh Tổ quốc, Sạch đường, sạch phố, sạch nhà, Bảo vệ môi trường ứng phó với biến đổi khí hậu ..., được xem như nguyên lý tâm linh quan trọng, hành động thiết thực của người Baha'i:

“Có nhũng nguyên lý tâm linh, hoặc nhũng điều mà có người gọi là nhũng giá trị nhân bản, dự vào đó người ta tìm ra giải pháp cho mọi vấn đề xã họi. Nói chung, bất cứ nhóm người có thiện ý nào cũng có thể tìm được giải pháp thực tế cho nhũung vấn đề của riêng mình, nhung thiện ý và sụ hiểu biết thực tế thuờng không đủ. Giá trị thiết yếu của nguyên lý tâm linh là nó không chỉ trình bày một viễn cảnh hòa hợp với bản chất con người, mà còn khơi dậy một thái độ, một sức mạh, một ý chí, một khát vong, giúp tìm ra và thực thi nhũung giải pháp thực tế. Nhũung nhà lãnh đạo các chính phủ và tất cả những người có thẩm quyền sẽ phụng sư tốt nhất trong nỗ lực giải quyết khó khăn, nếu truớc hết biết tìm nhũng nguyên lý liên hệ và làm theo sự huớng dẫn của nhũng nguyên lý đó" (Toà công lý Quốc tế, 2014, p. 13).

Thống kê các hoạt động bảo vệ môi trường của Cộng đồng tinh thần Baha’i Hà Nội qua một số nhóm ta có bảng số liệu sau:

\section{Bảng 2}

Số người tham gia các hoạt động bảo vệ môi trường của cộng đồng Baha’i Hà Nội tháng 06 đến tháng 12 năm 2020

\begin{tabular}{|c|c|c|}
\hline Các hoạt động (Người) & $\begin{array}{c}\text { Hội đồng tinh thần } \\
\text { Baha'i Hữu Bằng }\end{array}$ & $\begin{array}{c}\text { Hội đồng tinh thần } \\
\text { Baha'i Lê Đại Hành }\end{array}$ \\
\hline Trồng cây xanh tại các điểm công cộng & 89.0 & 90.0 \\
\hline
\end{tabular}




\begin{tabular}{|l|c|c|}
\hline \multicolumn{1}{|c|}{ Các hoạt động (Người) } & $\begin{array}{c}\text { Hội đồng tinh thần } \\
\text { Baha'i Hữu Bằng }\end{array}$ & $\begin{array}{c}\text { Hội đồng tinh thần } \\
\text { Baha'i Lê Đại Hành }\end{array}$ \\
\hline $\begin{array}{l}\text { Dọn dẹp vệ sinh khu cư dân và các điểm } \\
\text { công cộng }\end{array}$ & 70.0 & 87.0 \\
\hline $\begin{array}{l}\text { Thu gom, phân loại và xử lý rác thải sinh } \\
\text { hoạt }\end{array}$ & 60.0 & 65.0 \\
\hline $\begin{array}{l}\text { Bảo vệ nguồn nước, làm sạch môi trường } \\
\text { tại bãi giữa sông Hồng }\end{array}$ & 110 & 120 \\
\hline $\begin{array}{l}\text { Tuyên truyền phổ biến các chính sách } \\
\text { pháp luật về bảo vệ môi trường }\end{array}$ & 95.0 & 110 \\
\hline
\end{tabular}

Nguồn: Theo kết quả khảo sát của tác giả từ tháng 06 đến tháng 12 năm 2020

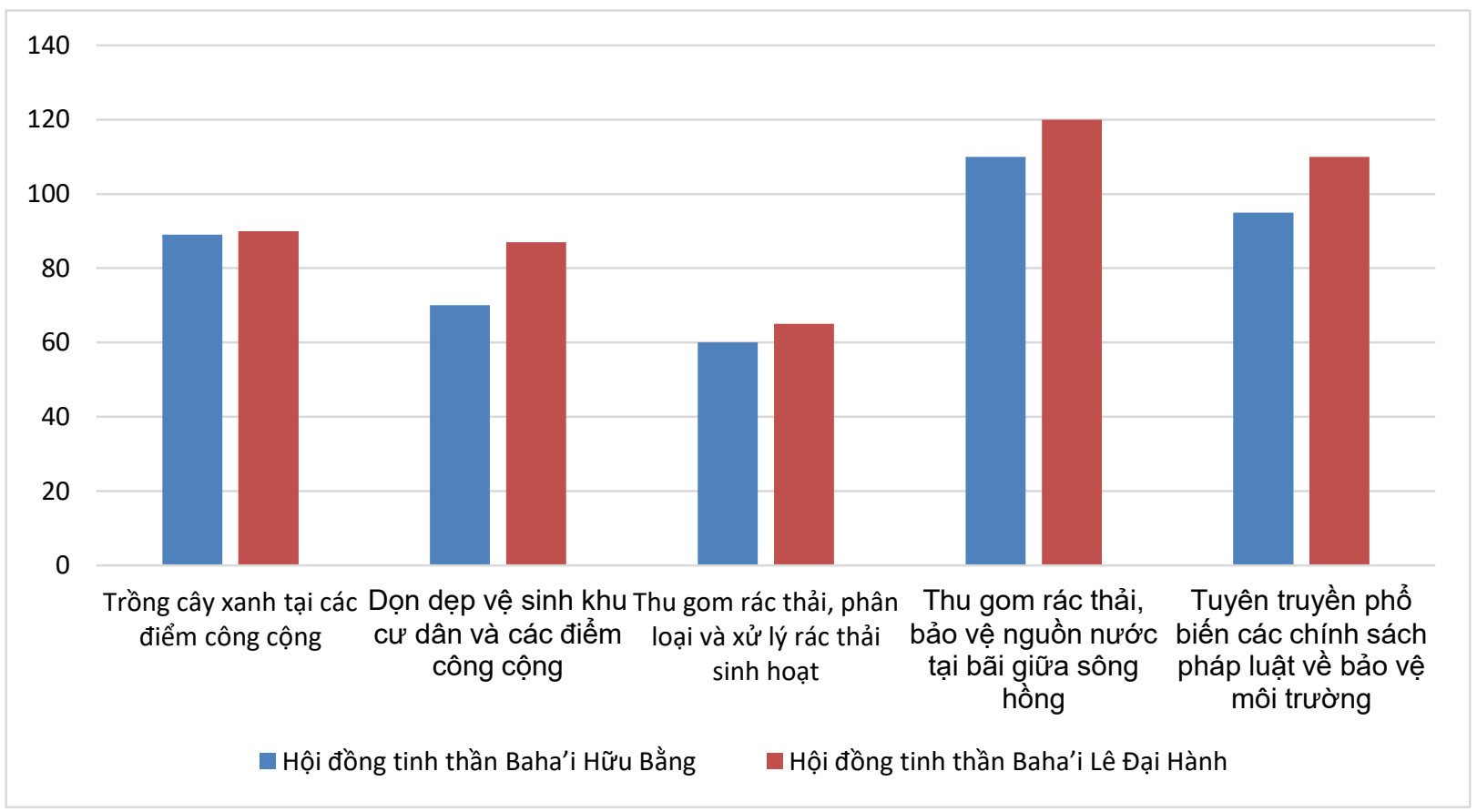

Hình 2. Số người tham gia các hoạt động bảo vệ môi trường của hai cộng đồng Baha’i Hữu Bằng và Lê Đại Hành từ tháng 06 đến tháng 12 năm 2020

Các số liệu trên chỉ ra rằng, ý thức bảo vệ môi trường được các tín đồ Baha'i Hà Nội tại các điểm nhóm của hai Hội đồng tinh thần Baha'i Hữu Bằng và Lê Đại Hành tiến hành có sự đa dạng về hình thức tổ, phong phú về hoạt động. Tuy nhiên, hoạt động thu hút được nhiều tín đồ tham gia vẫn là phong trào thu gom rác thải, bảo vệ nguồn nước tại bãi giữa sông Hồng tổ chức thường niên, hàng tuần và hàng tháng với những nhóm tình nguyện viên Baha'i tích cực làm sạch môi trường tại sông Hồng - không chỉ là dòng sông có ý nghĩa lịch sử và văn hoá, giữ vai trò quan trọng đối với môi trường sống của Hà Nội và các tỉnh lân cận. Tiếp đến là các hoạt động tuyên truyền, phổ biến chính sách pháp luật bảo vệ môi trường cũng được triển khai trong các cộng đồng tín đồ Baha'i Hà Nội. Hoạt động thu gom, phân loại và xử lý rác thải sinh hoạt cũng là hoạt động được triển khai tuy nhiên số lượng tín đồ tình nguyện chưa đông như các hoạt động khác tại cả hai cộng đồng tinh thần Baha'i địa phương Hà Nội bởi vì đây là hoạt động thiện nguyện đòi hỏi tình nguyện viên tham gia phải có những hiểu biết về kiến thức môi trường và 
phân loại rác, tính chuyên dụng cũng như mức độ độc hại cao hơn so với các hoạt động khác, vì vậy chưa thực sự thu hút được đông đảo tín đồ tham gia.

Tín đồ Baha'i Hội đồng tinh thần Hữu Bằng chị Đ. V. A. (Hàng Trống, Hà Nội) cho rằng:

“Hiện nay, vấn đề môi trương ô nhiễm, trái đất nóng lên và hiệu ưng nhà kính khiến cho thời tiết nhiều nơi trên trái đất rất khắc nghiệt. Đặc biệt, đối với Việt Nam nói chung và thủ đô Hà Nội nói riêng. Vấn đề này thể hiện rất rõ, nếu nhu trước kia Hà Nội có đủ 04 mùa và giũa các mùa là rất khác biệt về thời tiết. Hiện nay, mùa nào cũng thấy nóng, oi và bức trong mùa hè, lạnh và buốt mùa đông. Rồi cả nhũng vấn đề về thiên tai, lũ lụt ... Môi truờng thì chúng ta thấy rằng rác thải khắp nơi, dòng sông Tô Lịch giờ là dòng sông chết, nước Hồ Tây và Hồ gươm cũng ô nhiễm, sông Hồng cũng vậy, ... Nước thải sinh hoạt, rác thải công nghiệp, rác thải sinh hoạt tràn lan ... Nói chung, khi Cộng đồng tín hưu anh chị em trong đạo mình kêu gọi mọi người tham gia vào các hoạt động dù nhỏ thôi nhưng cũng đã là đóng góp sức mình một phần nào đó cho môi truòng sống của thủ đô được trong lành, dù bận công viẹcc, nhung ngày nghỉ mình luôn sẵn sàng tham gia cùng nhóm" [Phỏng vấn lúc 18h00, ngày 26 tháng 10 năm 2020, tại điểm sinh hoạt Hữu Bằng].

Cộng đồng tinh thần Baha'i Hà Nội nhận thức được rằng vai trò của con người vừa là đối tượng nhưng đồng thời cũng là chủ thể các hoạt động cải thiện của môi trường vì một hành tinh xanh, sạch, đẹp. Hơn nữa, những động cơ thiện và ý thức vì một xã hội lành mạnh, bền vững và phát triển cũng luôn thôi thúc con người cần phải hành động. Con người và môi trường là hai yếu tố tương hỗ, cộng sinh trong tính thống nhất chung của thế giới. Mọi sự thay đổi của con người cũng khiến cho môi trường thay đổi và ngược lại:

"Chúng ta không thế cách ly tâm hồn con người ra khỏi môi trường xung quanh chúng ta và nói rằng một khi một trong nhũ̃ng phần này được cải cách thì mọi sự sẽ được cái thiện. Con người tồn tại hữu cơ cùng thế giới. Cuộc sống nội tâm của con người hun đúc môi truờng và cũng chịu sụ tác động sâu xa của môi truờng. Mặt này tác động lên mặt kia và mọi sụ thay đổi mãi trong cuộc đời con người là kết quả sụ tác động qua lại của đôi bên" (Hội đồng tinh thần Baha'i Việt Nam, 1991, p. 84.)

Hay Thánh Abdu Baha chỉ bày: "Tất cả các thành viên của gia đình nhân loại, cho dù các dân tộc hay các chính phủ, các thành phố hay nông thôn, đã trở nên ngày càng phu thuộc lân nhau. Không còn cải gì có thế tư cung tự cấp nữa, bòi vì khi các mối quan hệ chính trị thống nhất tất cả các dân tộc và các quốc gia, và gắn kết thuơng mại và công nghiệp, nông nghiệp và giáo duc, đang được củng cố mỗi ngày. Vi thế, sụ thống nhất tất cả nhân loại có thể đạt được trong thời đại này" (Hội đồng tinh thần Baha'i Việt Nam, 2018b, p. 32).

Mặc dù, số lượng tín đồ Baha'i Hà Nội không quá lớn mạnh nhưng với tinh thần dấn thân, phục vụ, họ vẫn luôn tin tưởng và ý thức rõ về trách nhiệm của mình trong cộng đồng các tôn giáo dân tộc. Đặc biệt, trên lĩnh vực bảo vệ môi trường và sự ứng phó với biến đổi khí hậu. Mỗi thành viên trong cộng đồng, mỗi gia đình tín đồ Baha'i cũng là một phần của toàn thể nhân loại. Do đó, gia đình nhân loại cũng cần phải thể hiện trách nhiệm của mình trong vận mệnh toàn cầu.

Ba là, Cộng đồng tinh thần Baha'i Lê Đại Hành và Hũu Bằng với nhũng hoạt động bình đẳng giới

Giáo lý Baha’i luôn nhấn mạnh, ủng hộ cho phong trào bình đẳng giới trong một xã hội hiện đại. Quan điểm nam nữ bình quyền được Baha'i chia sẻ rộng rãi đến các tín đồ. Nguyên lý bình đẳng nam nữ được triệt để tôn trọng. Thánh Abdul Baha viểt rằng: "Nhân loại cũng giống nhu con chim có hai cánh, một cánh là nam giới, một cánh là nũ giới, nếu nhu hai cánh không mạnh bằng nahu và cư động do một sức mạn chung, thì con chim sẽ không thể bay lên cao 
đượ" (Hội đồng tinh thần Baha'i Việt Nam, 2018b, para. 2145). đẳng:

Thánh Baha'u'llah cũng dạy dưới mắt của Thượng Đế nam giới và nữ giới đều bình

"Đàn bà và đàn ông đã tìng, và sẽ mãi là bình đẳng trước mắt Thương Đế. Đấng Bình minh Ánh sáng của Thuợng Đế đã rọi hào quang lên vạn vật với vẻ huy hoàng nhu nhau. Quả thật, Thượng Đế đã tạo nên người nũ cho người nam, và người nam cho người nũu. Nhũ̃ng người đáng yêu nhất trong mắt Thuợng Đế là những ngườ kiên định nhất, và là nhũng nguời vuợt hơn ngườ khác trong tình yêu đối với Thương Đế, cao cả thay vinh quang của Ngài" (Hội đồng tinh thần Baha'i Việt Nam, 2018a, para. 2145).

Theo tinh thần này, những tín đồ Baha'i Hà Nội cũng có nhiều thay đổi về cách nhìn nhận của mình, đặc biệt trong đánh giá vấn đề bình đẳng nam nữ trong các quan hệ gia đình và xã hội. Đối với các xã hội hiện đại, nam nữ cần phải được bình đẳng với nhau trong cơ hội, vị trí việc làm, địa vị xã hội. Dưới đây là quan điểm chia sẻ về vấn đề bình đẳng nam nữ của hai Hội đồng tinh thần Baha’i địa phương Hà Nội là Lê Đại Hành và Hữu Bằng.

\section{Bảng 3}

Quan niệm bình đẳng giới trong cộng đồng Baha'i Hà Nội

\begin{tabular}{|l|c|c|}
\hline \multicolumn{1}{|c|}{ Quan niệm (\%) } & Hội đồng tinh thần Hữu Bằng & Hội đồng tinh thần Lê Đại Hành \\
\hline Nam quan trọng hơn nữ & 29.0 & 39.0 \\
\hline Nữ quan trọng hơn nam & 21.0 & 12.0 \\
\hline Nam nữ bình quyền & 50.0 & 49.0 \\
\hline
\end{tabular}

Nguồn: Theo kết quả khảo sát của tác giả (2020)
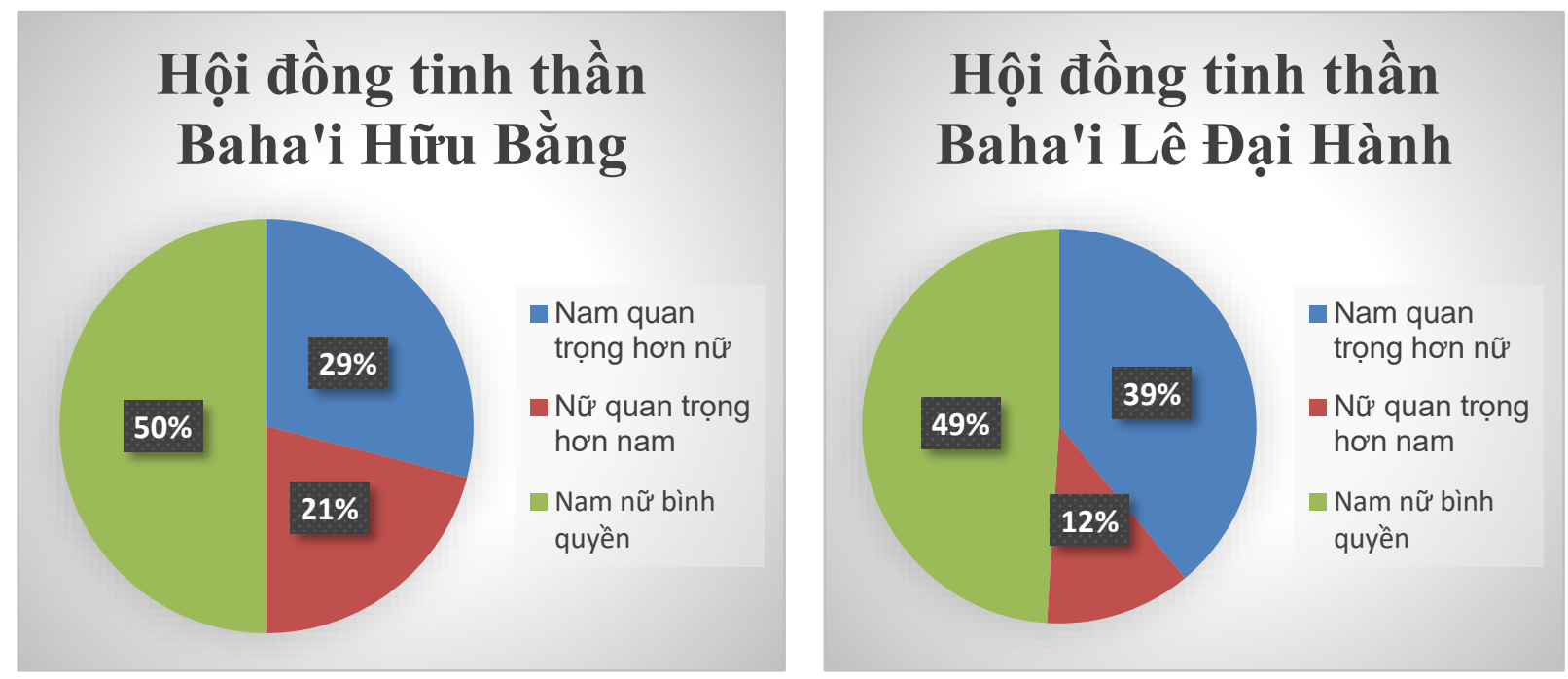

Hình 3. Quan niệm bình đẳng giới trong hai Hội đồng tinh thần Baha'i Hữu Bằng và Lê Đại Hành, Hà Nội

Trên biểu đồ cho thấy, nhờ những quan niệm bình đẳng giới được phổ biến đến đông đảo tín đồ Baha'i thông qua các hoạt động học tập trong giáo lý Baha'i. Các tín đồ Baha'i Hà Nội trên có những thay đổi tiến bộ trong quan niệm về giới $(50.0 \%$ tín đồ Hội đồng tinh thần Baha'i Hữu Bằng và 49.0\% tín đồ Hội đồng tinh thần Baha'i Lê Đại Hành đều đồng ý với quan niệm nam nữ bình quyền). Tuy nhiên, mặc dù theo giáo lý thì Đức Baha'u'llah vẫn khuyên tín 
đồ ưu tiên đối với người nữ giới và nữ giới là quan trọng hơn nên cần được tập trung đầu tư các cơ hội phát triển. Tuy quan điểm này của Baha'i là rất tiến bộ nhưng khi du nhập vào thủ đô Hà Nội, là một khu vực với truyền thống văn hoá lâu đời, chịu ảnh hưởng bởi các quan niệm phụ quyền và phong kiến tàn dư của xã hội cũ để lại, quan niệm "trọng nam khinh nữ" vẫn ảnh hưởng rất đậm và khó thay đổi, thậm chí vượt lên trên những quan niệm của tôn giáo. Có 29.0\% tín đồ Hội đồng tinh thần Baha'i Hữu Bằng và 39.0\% tín đồ Hội đồng tinh thần Baha'i Lê Đại Hành vẫn thừa nhận nam quan trọng hơn nữ. Tỉ lệ tín đồ cho rằng nữ quan trọng hơn nam theo đúng tinh thần của Baha'i chỉ đạt 21.0\% trong Hội đồng tinh thần Baha'i Hữu Bằng và $12.0 \%$ Hội đồng tinh thần Baha'i Lê Đại Hành. Điều này cho thấy, mặc dù có nhiều cố gắng nỗ lực để thay đổi quan niệm có phần cổ hủ, của tín đồ ở Baha'i là rất lớn nhưng chưa thực sự có hiệu quả một cách triệt để, hoàn toàn trong một môi trường truyền đạo có sự chi phối rất lâu đời của văn hoá, phong tục và nếp sống, quan niệm truyền thống.

Khi được hỏi về vấn đề này, một tín đồ Baha'i trong cộng đồng tinh thần Baha’i Lê Đại Hành T. Đ. H. (Cầu Giấy, Hà Nội) cũng chia sẻ:

"Đối với mình, dù rằng gia đình theo quan niệm truyền thống thì cũng rất coi trọng con trai, tuy nhiên vơ chồng mình thi lại vô cùng thoải mái. Cả hai vơ chồng đều không quan trọng việc sinh con trai hay con gái. Dù mình đã có hai con gái, nhưng gia đình chồng cũng muốn dùng các biện pháp khoa học hiện đại can thiệp để chọn và lọc sinh thêm cháu trai cho "có nếp có tẻ." Quả thưcc, vợ chồng mình đều thống nhất không sinh nũa. Được sự thông cảm và chia sẻ của chồng, đặc biệt khi tìm hiểu về Baha'i trong giáo lý hay các quy định cũng cho thấy tu tuởng bình đẳng rất rõ ràng, con trai cũng được, mà con gái cũng vậy. Đều là con nguời cá nên chúng ta phải tôn trọng nhau. Thực sự, các bé gái và phụ nũ trong xã hội truyên thống đã rất thiệt thòi rồi. Bản thân mình thấy quan điểm bình đẳng giới là vô cùng tiến bộ, rất hay là trong các lớp học tập cộng đồng của Baha'i mình cüng được các anh/chị giám viên cung cấp cho nhiều kiến thức về bình đẩng giới, nhũ̃ng vấn đề tiến bộ và các phong trào nũ quyền trên thế giới. Thưc sự mình thấy là phù hợp, it nhất đối với bản thân mình và rộng hơn là cả xã hội, nên nhìn nhận vấn đề này cởi mở hơn" [Phỏng vấn lúc 19h00, ngày 07 tháng 03 năm 2021, tại điểm sinh hoạt Hữu Bằng].

Như vậy, sự giáo dục quan điểm về bình đẳng giới và thực hiện bình đẳng giới trong đời sống gia đình và cộng đồng đối với tín đồ Baha'i cũng luôn được đánh giá rất cao. Điều này còn được thể hiện thông qua kết quả khảo sát quan niệm về sự phân chia công việc trong một gia đình và công việc xã hội trong tín đồ Baha'i:

\section{Bảng 4}

Quan niệm về sự phân công công việc của tín đồ Baha'i trong gia đình và xã hội

\begin{tabular}{|c|c|l|c|c|}
\hline \multirow{2}{*}{ STT } & $\begin{array}{c}\text { (Đơn vị } \\
\text { tỉ lệ \%) }\end{array}$ & \multicolumn{1}{|c|}{ Quan niệm } & Đồng ý & $\begin{array}{c}\text { Không } \\
\text { đồng ý }\end{array}$ \\
\hline \multirow{2}{*}{1} & \multirow{2}{*}{$\begin{array}{c}\text { Gia } \\
\text { đình }\end{array}$} & $\begin{array}{l}\text { Đàn ông chỉ kiếm tiền và lo các công to việc lớn } \\
\text { trong gia đình }\end{array}$ & 55.0 & 45.0 \\
\cline { 3 - 5 } & & $\begin{array}{l}\text { Chăm lo việc bếp núc, nuôi dạy con cái, chi tiêu và } \\
\text { sinh hoạt là nhiệm vụ của phụ nữ }\end{array}$ & 45.0 & 55.0 \\
\cline { 3 - 5 } & $\begin{array}{l}\text { Cả hai vợ chồng đều có trách niệm, nghĩa vụ và } \\
\text { quyền hạn trong gia đình như nhau }\end{array}$ & 70.0 & 30.0 \\
\cline { 3 - 5 } & Việc sinh con trai hay con gái là không quan trọng & 47.0 & 53.0 \\
\hline \multirow{2}{*}{2} & Xã hội & Đàn ông phải nắm giữ các vị trí quan trọng trong & 49.0 & 51.0 \\
\hline
\end{tabular}




\begin{tabular}{|c|c|l|c|c|}
\hline STT & $\begin{array}{c}\text { (Đơn vị } \\
\text { tỉ lệ \%) }\end{array}$ & \multicolumn{1}{|c|}{ Quan niệm } & Đồng ý & $\begin{array}{c}\text { Không } \\
\text { đồng ý }\end{array}$ \\
\hline & xã hội, cơ quan nơi làm việc & & \\
\cline { 2 - 4 } & $\begin{array}{l}\text { Phụ nữ chỉ nên lựa chọn những công việc nhẹ } \\
\text { nhàng và không nên tham gia vào nắm giữ cạc vị } \\
\text { trí quan trọng trong xã hội, cơ quan nơi làm việc }\end{array}$ & 30.0 & 70.0 \\
\cline { 2 - 4 } & $\begin{array}{l}\text { Đàn ông làm các công việc lãnh đạo tốt hơn phụ } \\
\text { nữ }\end{array}$ & 50.0 & 50.0 \\
\cline { 2 - 4 } & $\begin{array}{l}\text { Phụ nữ và đàn ông đều có bình đẳng và có năng } \\
\text { lực lãnh đạo như nhau, không phân biệt }\end{array}$ & 80.0 & 20.0 \\
\hline
\end{tabular}

Nguồn: Theo kết quả khảo sát của tác giả (2020)

Qua bảng số liệu cho thấy, rõ ràng có sự thay đổi trong quan niệm về vai trò và địa vị của nam và nữ trong xã hội cũng như trong gia đình ở các tín đồ Baha'i Hà Nội. Khi được hỏi về trách nhiệm và quyền hạn của vợ chồng trong gia đình thì $70.0 \%$ người được hỏi đồng ý rằng cả nam và nữ đều có trách nhiệm và quyền hạn như nhau. Chỉ có $30.0 \%$ không đồng ý với ý kiến này. Hoặc vai trò lãnh đạo của phụ nữ và đàn ông trong xã hội thì tỉ lệ đồng ý và không đồng ý đều là $50.0 \%$. Mặc dù, một số quan niệm sự thay đổi này thể hiện chưa thực sự khác biệt và vượt trội hơn hẳn so với các quan niệm truyền thống, do tính bền vững của văn hoá và tư tưởng truyền thống đã ăn sâu vào nếp nghĩ và lối tư duy, nhưng sự thay đổi này là đáng ghi nhận. Chẳng hạn khi được hỏi về việc sinh con trai và con gái là không quan trọng thì có $53.0 \%$ không đồng ý, trong đó tới $47.0 \%$ là đồng ý với ý kiến trên. Hoặc chỉ có $53.0 \%$ cho rằng đàn ông phải nắm giữ vị trí quan trọng trong xã hội hơn so với phụ nữ. Và $80.0 \%$ cho rằng phụ nữ và đàn ông là bình đẳng về năng lực lãnh đạo cũng như vị trí công việc.

Bốn là, Cộng đồng tinh thần Baha'i Lê Đại Hành và Hũu Bằng với nhũng hoạt động tùt thiện và an sinh xã họi

Hoạt động từ thiện và an sinh xã hội cũng là một trong những chương trình hành động của tín đồ Baha'i Việt Nam nói chung và cộng đồng Baha'i Việt Nam trên địa bàn thủ đô Hà Nội nói riêng. Theo đúng tôn chỉ được khẳng định trong "Hiến chuoong cộng đồng Baha'i Việt Nam," (Hội đồng tinh thần Baha'i Việt Nam, 2008, p. 5): "Hoạt động tuân thủ pháp luật Việt Nam, nêu cao tinh thần đoàn kết, hoà hợp dân tộc, hoà hợp tôn giáo; phấn đầu vì sự phát triển kinh tế, xã hội của đất nước, vì nền văn minh vật chất và tinh thần của nhân loại." Đồng thời, theo giáo lý của Baha'i, việc thực hiện các hoạt động từ thiện, an sinh xã hội để đảm bảo công bằng xã hội, giúp đỡ người nghèo khó là cần thiết đối với mỗi tín đồ để làm trọn nghĩa vụ với đạo của mình. Đấng Abdul Baha cho rằng: "Người giàu phải phân phối sự giàu có của mình cho người nghèo, đói, và với lòng thuơng mến, tì mẫn và sáng suốt, ho phải quan tâm đến nhũng kẻ khốn khó đang đau khổ vì thiếu thốn cả nhũng điều cần thiết nhất để sống” (Esselmont, 1987, p. 184).

Và trong bức thư viết năm 1919, Abdul Baha lại viết: "Trong các giáo huấn của Baha'u'llah có điều nói về vấn đề tình nguyện phân chia tài sản; sư tình nguyện phân chia tài sản này đáng khen hơn là sụ quân phân (do luật pháp bắt buộc) và dựa trên sụ kiện là, ta không được ... yêu ta hơn đồng loại, mà trái lại phải hi sinh tính mạng, tài sản của mình cho kẻ khác ... Con người phải sã̃n lòng, và hoàn toàn do thiện chí mà hi sinh tài sản và tính mạng của mình cho nhũng kẻ nghèo khó cũng như người Baha'i ở Ba Tư thường có lệ ấy" (Esselmont, 1987, p. 185).

Mỗi người ngoài việc chăm lo cho đời sống của chính mình thì còn có nghĩa vụ chăm lo 
cho đời sống cộng đồng và những người khác. Bởi đối với người Baha’i, Đức Shoghi Efendi trong giáo huấn của mình cũng nhấn mạnh: "Sống theo Giáo lý của Chính đạo là mối quan tâm cao nhất của mỗi tín đồ chân chính ... Chính đạo Baha'i khuyến khích cuộc sống cộng đồng, và có nghĩa vu giúp mối tín đồ trở thành thành viên sống động, hoàn toàn tích cực và có trách nhiệm trong tình huynh đệ Baha'i toàn cầu" (Hội đồng tinh thần Baha'i Việt Nam, 1991, para. 1570).

Hay: "Đời sống cộng đồng Baha'i bao hàm ý nghĩa là ý thức về sụ đoàn kết với nhau mạnh mẽ đến nỗi mối cá nhân có thể quên đi điều thiết yếu riêng tu cho hạnh phúc chung" (Hội đồng tinh thần Baha'i Việt Nam, 1991, para. 1217).

Và trong giáo luật Baha'i cũng quy định bắt buộc đối với tín đồ, hàng năm, đặc biệt vào dịp lễ Ayyam-i-Ha (Dư Nhật), từ ngày 25 đến hết tháng 02 dương lịch. Cộng đồng tôn giáo Baha'i tổ chức các hoạt động từ thiện nhân đạo và các chương trình phát triển cộng đồng. Đây là những ngày dư để điều chỉnh Niên lịch Baha'i theo hệ mặt trời. Vì Niên lịch Baha'i mỗi năm có 19 tháng, mỗi tháng có 19 ngày $(19$ x $19=361$ ngày), để điều chỉnh cho đúng chu kỳ của một năm theo hệ mặt trời gồm 365 ngày và có phần lẻ. Như vậy, năm thường có 04 ngày dư và năm nhuận có 05 ngày dư (nên những ngày này gọi là Dư Nhật). Những ngày này được đặt vào giữa tháng thứ 18 và tháng thứ 19 . Đức Baha'u'llah khuyên dùng những ngày này vào việc tiếp khách, hiếu hỉ và làm từ thiện, Việc làm này tuỳ theo mỗi cộng đồng nhưng tập trung vào các việc như: cộng đồng giúp đỡ những người nghèo khó xây dựng lại căn nhà xiêu vẹo, có thể giúp những người trong cộng đồng Baha'i, hoặc người thuộc các tôn giáo khác khi họ cần giúp đỡ, ủng hộ đồng bào chịu thiên tai, lũ lụt, thăm nom những cơ sở chăm sóc trẻ mồ côi, viện dưỡng lão, giúp đỡ những người vô gia cư ... (Dieu Phuc, 2016, p. 42).

Đối với cộng đồng Baha'i Hà Nội, cả hai Hội đồng tinh thần địa phương cũng đã có những hoạt động thiết thực hỗ trợ cộng đồng trong công tác từ thiện và an sinh xã hội. Trên tinh thần giáo lý, giáo luật, hai nhóm cộng đồng Baha'i Hà Nội trong những năm qua cũng đã tổ chức và phát động các chương trình ủng hộ người nghèo, giúp đỡ người vô gia cư và người già cô đơn, thăm viện các trung tâm bảo trợ xã hội và trại trẻ mồ côi, trung tâm nuôi dưỡng người già cô đơn không nơi nương tựa ... Theo thống kê của Hội đồng tinh thần Baha'i Lê Đại Hành, và Hữu Bằng trong 05 năm trở lại đây (từ 2015 đến 2020), một số nhóm tín đồ Baha'i trong cộng đồng Baha'i Hà Nội đã tham gia các hoạt động từ thiện, an sinh xã hội thường niên, cụ thể như sau:

\section{Bảng 5}

Thống kê sơ bộ của các nhóm hoạt động cộng đồng thuộc hai Hội đồng tinh thần Baha’i Hữu Bằng và Lê Đại Hành tại thủ đô Hà Nội trong các hoạt động từ thiện, an sinh xã hội

\begin{tabular}{|c|l|c|c|c|c|}
\hline \multirow{2}{*}{ STT } & Các hoạt động tham gia & \multicolumn{3}{|c|}{ Năm (Số tiền/số lần) } \\
\cline { 3 - 6 } & $\mathbf{2 0 1 6}-$ & $\mathbf{2 0 1 7 - 2 0 1 8}$ & $\mathbf{2 0 1 8} \mathbf{2 0 1 9}$ & $\begin{array}{c}\mathbf{2 0 1 9} \text { - } \\
\mathbf{2 0 2 0}\end{array}$ \\
\hline \multirow{2}{*}{1} & $\begin{array}{l}\text { Ủng hộ đồng bào chịu } \\
\text { hậu quả thiên tai, lũ lụt, } \\
\text { dồng bào chịu ảnh hưởng } \\
\text { của dịch bệnh Covid 19 } \\
\text { (2020) }\end{array}$ & $200 \mathrm{tr} / 4$ lần & $250 \mathrm{tr} / 5$ lần & $300 \mathrm{tr} / 5$ lần & $\begin{array}{c}400 \mathrm{tr} / 6 \\
\text { lần }\end{array}$ \\
\hline 2 & $\begin{array}{l}\text { Giúp đỡ người vô gia cư, } \\
\text { người nghèo khó, trẻ em }\end{array}$ & $100 \mathrm{tr} / 9$ lần & $150 \mathrm{tr} / 8$ lần & $200 \mathrm{tr} / 8$ lần & $\begin{array}{c}150 \text { tr/6 } \\
\text { lần }\end{array}$ \\
\hline
\end{tabular}




\begin{tabular}{|c|l|c|c|c|c|}
\hline \multirow{2}{*}{ STT } & \multirow{2}{*}{ Các hoạt động tham gia } & \multicolumn{3}{|c|}{ Năm (Số tiền/số lần) } \\
\cline { 3 - 6 } & $\begin{array}{c}\mathbf{2 0 1 6}- \\
\mathbf{2 0 1 7}\end{array}$ & $\mathbf{2 0 1 7 - \mathbf { 2 0 1 8 }}$ & $\mathbf{2 0 1 8 - \mathbf { 2 0 1 9 }}$ & $\begin{array}{c}\mathbf{2 0 1 9}- \\
\mathbf{2 0 2 0}\end{array}$ \\
\hline & $\begin{array}{l}\text { mồ côi, người già cô đơn } \\
\text { không nơi nương tựa }\end{array}$ & & & & \\
\hline 3 & $\begin{array}{l}\text { Thăm trung tâm bảo trợ } \\
\text { xã hội, trại trẻ mồ côi } \\
\text { viện dưỡng lão,... }\end{array}$ & 50 tr/4 lần & 60 tr/5 lần & 60 tr/5 lần & 50 tr/4 lần \\
\hline 4 & $\begin{array}{l}\text { Các hoạt động từ thiện, } \\
\text { an sinh xã hội khác }\end{array}$ & 80 tr/10 lần & 100 tr/12 lần & $120 \mathrm{tr} / 15$ lần & 50 tr/5 lần \\
\hline
\end{tabular}

Nguồn: Tổng hợp của tác giả dựa trên các báo cáo tổng kết hoạt động của Cộng đồng tinh thần Baha'i Hà Nội giai đoạn 2015 - 2020s

Qua bảng số liệu cho thấy, trong các hoạt động từ thiện và an sinh xã hội, tín đồ Baha'i Hà Nội tham gia rất tích cực. Từ thiện và an sinh xã hội được xem như một nhiệm vụ quan trọng hàng năm mà mỗi tín đồ Baha'i phải thực hiện, cũng giống như những quy định về nghĩa vụ bố thí (Zakat) của Islam, và nhiều tôn giáo khác. Việc khuyến khích các tín đồ làm việc thiện cũng chính là thể hiện hành động và tư tưởng gắn đạo với đời, tinh thần hướng thiện của tôn giáo. Khi được hỏi về trách nhiệm của mình trong các hoạt động từ thiện, an sinh xã hội, tín đồ Baha’i N.V.K (Hàng Gai), thuộc Hội đồng tinh thần Lê Đại Hành chia sẻ:

"Từ thiện xã hội là một việc làm cần thiết mà mọi tín đồ Baha'i phải làm. Theo nhu qui định trong giáo lý và giáo luật Baha'i thì các dụ án phát triển cộng đồng cũng nhấn mạnh các tín đồ phải tích cực tham gia vào nhũng chuoong trình nhu giáo dục sức khoẻ, dinh duỡng cho cộng đồng, chuoong trình giúp đõ nhau phát triển kinh tế, xoá mù chũ, mở các chuơng trình, lớp học nâng cao tri thức khoa học, giúp đõ̃ người nghèo, hỗ trọ̣ các trung tâm bảo trọ xã hội, trại trẻ mồ côi, giúp đỡ người vô gia cu ... Khi thực hiện nhũng hoạt động này, bản thân chúng tôi tin chắc rằng không chỉ là những đóng góp nhỏ bé của mình đối với những nguời kém may mắn trong xã hội, đỡ đần, chung tay, góp một phần sức lực nhỏ bé cho nhũng gánh nặng xã hội và tạo ra sụ bình đẳng cho xã hội một phần nào đó. Đồng thời xem xét trên phuơng diện đức tin, chúng tôi tin rằng những hành động tốt đẹp dù nhỏ bé nhất của chúng tôi cũng được Thượng Đế thấu suốt và Thượng Đế sẽ ban ơn, che chở cho chúng tôi đời đờì" [Phỏng vấn được thực hiện thời gian 19h30' ngày 19 tháng 09 năm 2020, tại điểm sinh hoạt Hội đồng tinh thần Baha'i Lê Đại Hành].

Ngoài ra, các nhóm Cộng đồng Baha'i Việt Nam tại thủ đô Hà Nội cũng luôn tuân thủ pháp luật của đất nước, tích cực tham gia vào các phong trào xây dựng khu phố văn hoá, sống và học tập làm việc theo Hiến pháp và Pháp luật của Nhà nước, phụng sự chính đạo. Thánh kinh Baha'i dạy: “Tại mỗi nước nơi tín đồ Baha'i cư trú, họ phải cư xử với chính phủ nước ấy bằng sự trung thành, lương thiện và trung thực. Đây là điều đã được mặc khải theo phán lệnh của Ngài là Đấng An Bài, Đấng Cố Cựu của các Thời đại” (Thao Nguyen, 2019, pp. 40-42).

Để tăng cường liên tôn, hoà hợp, hàng năm Cộng đồng tôn giáo Baha'i ở các tỉnh thành và trên địa bàn thủ đô Hà Nội đều thực hiện "Ngày Tôn giáo Hoàn Cầu" mời lãnh đạo các tôn giáo cùng chủ toạ cho buổi lễ và tín đồ của các cộng đồng tôn giáo khác nhau cùng họp mặt để giúp tín đồ cũng như đồng bào thấy được sự yêu thương và hoà hợp giữa các tôn giáo. Cộng đồng Baha'i cũng thực hiện các nhóm hoạt động cốt lõi là Nhóm Cầu Nguyện, Nhóm Học tập, Nhóm Thiếu Nhi và Nhóm Thiếu niên để đóng góp cho cộng đồng xã hội nói chung những định hướng họ thành những công dân tốt, đoàn kết, gắn bó, san sẻ yêu thương, đùm bọc, biết hy sinh 
lợi ích cá nhân cho hạnh phúc chung của xã hội. Những hoạt động này được thực hiện trong khu dân cư nơi mà người Baha'i sinh sống, qua đó tình xóm giềng được thắt chặt, sự hiểu biết về hành trình xây dựng văn hoá tâm linh và vật chất được diễn ra và trên hết là hành trình mưu cầu hạnh phúc có thể được vun đắp, cũng là cách thức để chung tay cùng chính quyền xây dựng đất nước ngày càng thịnh vượng.

\subsection{Thảo luận}

Trên cơ sở các kết quả nghiên cứu, tác giả rút ra một số thảo luận cho vấn đề nghiên cứu này, cụ thể như sau:

Thứ nhất, Baha'i là một tôn giáo với nội dung giáo lý cởi mở, chứa đựng những giá trị hướng thiện về một xã hội loài người với những khao khát xây dựng môi trường sống an lành, phồn vinh và hạnh phúc. Đạo đức và tinh thần Baha'i hướng đến cho tín đồ và cộng đồng xã hội là xây dựng, củng cố niềm tin giữa con người với con người, sự chia sẻ, thấu cảm và giúp đỡ lẫn nhau trong mọi hoàn cảnh, hướng đến một xã hội mà nhân loại sống trong tình thương yêu hoà hợp, bình đẳng, văn minh và công bằng. Các hoạt động trên mọi lĩnh vực xã hội của Baha'i quốc tế và Cộng đồng Baha'i Việt Nam nói chung, Cộng đồng Baha'i thủ đô Hà Nội nói riêng trong những năm qua có ý nghĩa quan trọng góp phần tạo nên sự thay đổi nhận thức, tư duy và hành vi của các tín đồ cũng như với cộng đồng dân cư, với xã hội của nhiều quốc gia, Việt Nam và thủ đô Hà Nội có giá trị thúc đẩy sự phát triển tiến bộ của xã hội. Chính vì vậy, câu hỏi thảo luận tác giả đặt ra sau nghiên cứu này là: Baha'i là một tôn giáo đang trong quá trình truyền bá và phát triển ở Việt Nam, đứng trên phương diện quản lý Nhà nước cũng như bản thân tôn giáo này, làm thế nào để phát huy hơn nữa giá trị và vai trò của nó, đồng thời khắc phục những khó khăn, hạn chế trong thực tiễn hoạt động?

Thứ hai, đối với Cộng đồng Baha’i thủ đô Hà Nội, cả hai Hội đồng tinh thần Hữu Bằng; Lê Đại Hành vẫn đang trong quá trình hình thành, xây dựng, truyền bá và phát triển tín đồ cũng như hoàn thiện về tổ chức của cộng đồng. Do đó, Baha'i Hà Nội gặp không ít những khó khăn: là một tôn giáo mới được Công nhận trong khoảng thời gian gần 15 năm (2007 - 2021), hiện còn khá xa lạ ở Việt Nam và chưa được nhiều người biết đến, lại đặt trong mối quan hệ với các tôn giáo lớn có truyền thống lâu đời tồn tại và phát triển như Phật giáo, Công giáo, Islam, ..., vì vậy rất khó để có thể thu hút được tín đồ cũng như khẳng định được vị thế của mình trong cộng đồng xã hội; Hơn nữa, những hoạt động của hai nhóm tín đồ trong Hội đồng tinh thần Baha'i Hữu Bằng và Lê Đại Hành trong những năm qua, mặc dù có nhiều cố gắng để quảng bá đến cộng đồng, tuy nhiên, do số tín đồ còn ít, nguồn kinh phí hoạt động hạn hẹp, mối liên hệ với các tổ chức xã hội khác như Mặt trận Tổ quốc các cấp, Uỷ ban nhân dân các cấp, Hội phụ nữ, Hội Thanh niên ... còn hạn chế, vì vậy, trong các hoạt động của họ, sự hỗ trợ của các tổ chức chưa thực sự hiệu quả và rõ ràng; hoặc do tổ chức nhỏ, lẻ cũng bộc lộ nhiều hạn chế trong hoạt động và kêu gọi sự đóng góp của tín đồ; Khó khăn về cơ sở hoạt động cũng như thực hành tôn giáo còn chưa cố định, đôi khi phải mượn nhà riêng của tín đồ để tổ chức các hoạt động thực hành đạo ... Bên cạnh đó, Cộng đồng Baha'i Hà Nội trong quá trình hoạt động cũng bộc lộ không ít những hạn chế như: các hoạt động của tín đồ nhiều khi mang tính nhóm, lẻ tẻ, tự phát vì vậy rất khó quản lý, mức độ lan toả của hoạt động đến với cộng đồng ngoài tôn giáo chưa thực sự tạo thành điểm nhấn và tính đột phá; mức độ ảnh hưởng, mức độ lan tỏa về tư tưởng, về hành động của cộng đồng này với những người dân không theo tôn giáo này chưa hiệu quả. Đây cũng chính là những khó khăn và hạn chế của Cộng đồng Baha'i Việt Nam nói chung và Hà Nội nói riêng, vấn đề đặt ra cho sự phát triển của cộng đồng tôn giáo này là làm sao để có thể khắc phục được những khó khăn và hạn chế đỏ, tăng cường hơn nữa những ảnh hưởng đến với cộng đồng?

Thứ ba, căn cứ vào những kết quả nghiên cứu về Cộng đồng Baha'i Việt Nam trong việc thực hiện chức năng xã hội trên địa bàn thủ đô Hà Nội cũng phần nào cho thấy, mặc dù là một 
tôn giáo khá non trẻ, được du nhập và phát triển ở Việt Nam, và thủ đô Hà Nội nhưng tôn giáo Bahai bằng những hoạt động thiết thực và có ý nghĩa đóng góp cho đời sống con người và vì sự tiến bộ, phát triển xã hội đã bước đầu dần khẳng định được vị thế của mình trong đời sống tôn giáo ở Việt Nam và nhiều địa phương nơi nó du nhập. Điều này cho phép dự đoán rằng, trong thời gian tới Tôn giáo Baha'i Việt Nam, Hội đồng tinh thần Baha'i địa phương và Cộng đồng tinh thần Baha'i thủ đô Hà Nội nói riêng sẽ có những bước phát triển mới, không ngừng tăng lên về số lượng cũng như sự ảnh hưởng của mình trong cộng đồng. Đặc biệt, căn cứ vào thực tiễn của xã hội Việt Nam đang có nhiều chuyển biến, sự chuyển biến tôn giáo cũng sẽ là tất yếu và không thể tránh khỏi. Điều này, có thể sẽ tạo điều kiện cho Baha'i có được cơ hội để truyền bá rộng hơn trong cộng đồng người Việt. Để làm được điều này, bản thân Baha'i Việt Nam nói chung, cộng đồng tinh thần Baha'i thủ đô Hà Nội nói riêng phải không ngừng cải biến, nhập thế, dấn thân và bám sát vào tình hình thực tiễn để có thể có sư thích nghi phù hợp với truyền thống, nhận thức, tinh thần và văn hoá bản địa Việt Nam. Phải chăng, hiện nay, mặc dù gần 15 năm du nhập và phát triển nhưng Baha'i Việt Nam, Baha'i thủ đô Hà Nội vẫn chưa thích ứng và bắt kịp các các căn cứ thực tiễn, căn cứ lý luận (bao hàm cả những nguyên nhân khách quan về mức độ của sự phù hợp hay không phù hợp của tôn giáo này với các yếu tố tư duy, tinh thần, nhận thức, các yếu tố văn hóa truyền thống và hệ thống các tôn giáo lâu đời của người dân Việt Nam ... có thể là những nguyên nhân dẫn đến sự chậm phát triển của tôn giáo này tại Việt Nam);

Thứ tư, nghiên cứu này có thể là một vấn đề được đặt ra nhằm góp phần giải đáp và tham vấn bài toán làm thế nào để Baha'i có thể khẳng định được vị thế của mình ở Việt Nam nói chung và thủ đô Hà Nội nói riêng hiện nay? Việc sử dụng các kết quả nghiên cứu này có thể hữu ích để thực hiện nhiệm vụ tham mưu, tư vấn cho các cơ quan, tổ chức có chức năng quản lý nhà nước về tôn giáo trong xây dựng các chính sách quản lý đối với cộng đồng Baha'i Việt Nam. Trên cơ sở đó, thúc đẩy cộng đồng này phát huy những giá trị tích cực đối với sự phát triển của xã hội.

\section{Kết luận}

Là một tôn giáo với phương châm hoà hợp vì sự tiến bộ, văn minh và hoà bình trên toàn cầu. Cộng đồng Baha'i quốc tế với những chương trình phát triển sâu rộng nhằm dấn thân cho một xã hội bền vững theo tinh thần mới của Đức Baha'u'llah. Mục đích chính yếu của Baha'i là tăng cường các chức năng xã hội, hướng thiện và hoà mình vì nhân loại trong thực tiễn, đồng thời đề cao tinh thần Chân, Thiện, Mĩ. Tôn giáo Baha'i với mong muốn trong phạm vi của mình xây dựng cho nhân loại, cũng như các quốc gia một đời sống tốt đẹp hơn. Những dự án xoá đói, giảm nghèo, xoá mù chữ, chăm sóc y tế cộng đồng, bảo vệ môi trường sống hay các việc làm nhỏ mang ý nghĩa lớn của cá nhân như sách hoá nông thôn đều đáng được ngợi ca và tỏ rõ thiện tâm. Cũng như các thành phần khác trong xã hội loài người, cộng đồng Baha'i Việt Nam nói chung, cộng đồng Baha'i Hà Nội nói riêng có nhiều đóng góp cho hoạt động xã hội. Điều này thể hiện khao khát của cộng đồng về một môi trường sống an lành, phồn vinh và hạnh phúc. Trong đó, người với người có niềm tin với nhau, cảm nhận được niềm vui, nỗi buồn của nhau, giúp đỡ, chia sẻ vượt qua mọi hoàn cảnh. Cộng đồng Baha'i thủ đô Hà Nội với hai Hội đồng tinh thần Baha'i là Hữu Bằng và Lê Đại Hành đã và đang có những cố gắng nỗ lực không chỉ trên phương diện giáo dục đạo đức, lối sống cho tín đồ, từ thiện an sinh xã hội và bảo vệ môi trường sống nhằm thể hiện rõ chức năng xã hội của mình. Những dự án, hoạt động mà các nhóm tín đồ trong cộng đồng Baha'i đang triển khai có ý nghĩa thiết thực góp một phần nhỏ bé vào việc xây dựng một thủ đô văn minh, thanh lịch, sạch đẹp, giàu mạnh.

\section{Tài liệu tham khảo}

Ban Tôn giáo, Sở Nội vụ Hà Nội. (2020). Báo cáo tổng kết tình hình và hoạt động tôn giáo tại 
Hà Nội giai đoạn 2015 - 2020 [Summary report on religious situation and activities in Hanoi for the period 2015 - 2020]. Hanoi, Vietnam: Ban Tôn giáo - Sở Nội vụ Hà Nội.

Bobineau, O. J., \& Storper, S. T. (2012). Xã hội học tôn giáo [Sociology of religion]. Hanoi, Vietnam: NXB Thế giới, Hà Nội.

Dieu Phuc (2016). Cộng đồng tôn giáo Baha'i Việt Nam đóng góp cho một xã hội tốt đẹp hơn, một thế giới tốt đẹp hơn [The Baha'i Vietnam spiritual community contributes to a better society, a better world]. Tạp chi Công tác Tôn giáo, (1/2), 41-43.

Durkheim, E. (2008). The elementary forms of religious life (J. Swain, Trans). Glencoe, IL: Oxford University Press.

Duy Nguyen (2009). Đại hội lần thứ hai Cộng đồng tôn giáo Baha'i Việt Nam thành công tốt đẹp [The second congress of the Vietnam Baha'i religious community was a great sucess]. Tap chí Công tác Tôn giáo, (5), 2-3.

Esselmont, E. J. (1987). Baha'u'llah và kỷ nguyên móri [Baha'u'llah and the New Era]. Ho Chi Minh City, Vietnam: Hội đồng tinh thẩn Địa phương Chi Đạo Baha’i Sài Gòn dịch và ấn tống.

Hong Ly (2008). Lễ trao quyết định công nhận tổ chức cho cộng đồng tôn giáo Baha'I [Cremony of awarding the decision to recognize the organization for the Baha'i religious community]. Tạp chí Công tác Tôn giáo, (8), 5-28.

Hội đồng tinh thần Baha'i Việt Nam. (1991). Đức Shoghi Effendi, Tuyển tập quyển 1 [Holy Shoghi Effendi, Anthology, volume 1]. Ho Chi Minh City, Vietnam: Cộng đồng Baha'i ấn tống.

Hội đồng tinh thần Baha'i Việt Nam. (1998). Cộng đồng Baha'i Quốc tế (tài liẹu được soạn cho Tôn giáo Thế giới và Đối thoại Phát triển 02 - 1998) [International Baha'i community (document prepared for World Religion and Development Dialogue February - 1998)]. Ho Chi Minh City, Vietnam: Cộng đồng tinh thần Baha'i Thành phố Hồ Chí Minh ấn tống.

Hội đồng tinh thần Baha'i Việt Nam. (2008). Hiến chuoong cộng đồng Baha'i Việt Nam [Charter of the Vietnam Baha'i community]. Ho Chi Minh City, Vietnam: Cộng đồng tinh thần Baha'i Thành phố Hồ Chí Minh ấn tống.

Hội đồng tinh thần Baha'i Việt Nam. (2010). Thông điệp Ridvan 2010 của Toà công lý Quốc tế [Message of Ridvan 2010 of the International court of jusice]. Ho Chi Minh City, Vietnam: Cộng đồng tinh thần Baha'i Việt Nam.

Hội đồng tinh thần Baha'i Việt Nam. (2016). Cộng đồng Baha'i Quốc tế, Một đức tình Chung, [International Baha'i community, A common vitture]. Ho Chi Minh City, Vietnam: Cộng đồng Baha'i Việt Nam ấn tống.

Hội đồng tinh thần Baha'i Việt Nam. (2018a). Đúc AbdulBaha [Holy AbdulBaha]. Hanoi, Vietnam: NXB Tôn giáo.

Hội đồng tinh thần Baha'i Việt Nam. (2018b). Trích Thánh thu của Đức Baha 'u'llah [Excerpts from the Holy scriptures of Baha'u'llah]. Hanoi, Vietnam: NXB Tôn giáo.

Hội đồng tinh thần tôn giáo Baha'i Việt Nam. (2011a). Tôn giáo Baha'i giới thiệu tổng quát [General introduction Baha'i religion]. Hanoi, Vietnam: NXB Tôn giáo.

Hội đồng tinh thần Tôn giáo Baha'i Việt Nam. (2011b). Thánh kinh thiêng liêng nhất, Kitab Iaqdas, Đúc Baha'u'llah [The most holy bible, Kitab Iaqdas, Baha'u'llah]. Ho Chi Minh City, Vietnam: Cộng đồng Baha'i Việt Nam ấn tống.

Hội đồng tinh thần Tôn giáo Baha'i Việt Nam. (2014). Tạo nên trí tuệ mới [Creating a New Mind]. Ho Chi Minh City, Vietnam: Cộng đồng Baha’i Việt Nam ấn tống. 
Hội đồng tinh thần Tôn giáo Baha'i Việt Nam. (2015). Nhũng người khai sáng [Dawn Breakers for Children]. Ho Chi Minh City, Vietnam: Cộng đồng Baha'i Việt Nam ấn tống.

Hội đồng tinh thần Tôn giáo Baha'i Việt Nam. (2016). Nhũng bài giảng của Đức Abdul Baha tại Paris (Paris Talks) [Lectures of Abdul Baha in Paris]. Ho Chi Minh City, Vietnam: Cộng đồng Baha'i Việt Nam ấn tống.

Hội đồng thần Baha'i Việt Nam. (2020). Báo cáo tổng kết hoạt động của Cộng đồng tinh thần Baha'i Hà Nộ giai đoạn 2015 - 2020 [Final report of Baha'i spiritual community in Hanoi 2015-2020]. Hanoi, Vietnam: Cộng đồng tinh thần Baha'i Hà Nội.

Malinowski, B. (2006). Ma thuật, khoa học và tôn giáo [Magic, Science and Religion]. In Nhũng vấn đề nhân học tôn giáo [Religious Anthropology issues] (pp. 147-213). Danang, Vietnam: Hội Khoa học Lịch sử Việt Nam, Tạp chí Xưa và Nay, NXB Đà Nẵng.

Malinowski, B. (2010). Magic, science and religion. Whitefish, MT: Kessinger Legacy Reprints.

Marx, K., \& Engels, F. (1995). Toàn tập (t.1) [Complete Works, vol. 1]. Hanoi, Vietnam: NXB Chính trị Quốc gia, Hà Nội.

Nguyen, V. H. (1986). "Bút kí triết học” của V. Lênin, cơ sở phương pháp luận nghiên cứu chức năng xã hội của tôn giáo ["Philosophical memoirs" of V.I.Lenin, methodological basis for studying the social function of religion]. Tạp chí Khoa hoc, Truòng Đại hoc Tổng hợp Hà Nộ $i, 2,13-16$.

Nguyen, X. T. (2020). Tôn giáo và chính sách tôn giáo ở Việt Nam [Religion and religious policy in Vietnam]. Hanoi, Vietnam: NXB Tôn giáo.

Olivier Bobineau Sebastien Tank Storper. (2012). Xã hội học tôn giáo [Sociology of Religion] (Hoang Thach, Trans). Hanoi, Vietnam: NXB Thế giới.

Stein, R., \& Stein, P. L. (2005). Anthropology of religion, magic and witchcraft (4th ed.). New York, NY: Routledge.

Styers, R. G. (2004). Making magic: Religion, magic and science in the modern world, American Academy of religion reflection and theory in the study of religion series. New York, NY: Oxford University Press.

Toà Công lý Quốc tế. (2014). Lời hứa hoà bình thế giới [Promise of world peace]. Ho Chi Minh City, Vietnam: Cộng đồng Baha'i Việt Nam ấn tống.

Toan Anh (1972). Nếp cũ - Tín nguõng Việt Nam (quyển hạ) [Old sticky rice - Vietnamese beliefs (Low book)]. Ho Chi Minh City, Vietnam: NXB Sài Gòn.

Tylor, E. B. (2001). Văn hóa nguyên thủy [Primitive culture] (Huyen Giang, Trans). Hanoi, Vietnam: NXB Văn Hóa Nghệ Thuật.

Thao Nguyen (2019). Tín đồ Baha'i Việt Nam luôn chấp hành tốt luật pháp, giữ gìn sự đoàn kết các tôn giáo khác, cùng nhau sống tốt đời - đẹp đạo [Baha’i followers in Vietnam always obey the law well, maintain the unity of other religions, live a good life together]. Tạ chi Công tác Tôn giáo, (1/2), 40-42.

Weber, M. (1993). The sociology of religion (E. Fischoff, Trans). Boston, MA: Beacon Press. 


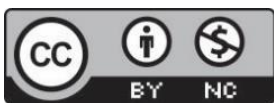

Creative Commons Attribution-NonCommercial 4.0 International License. 